\title{
THE GENUS HYDROLITHON FOSLIE (CORALLINALES, RHODOPHYTA) ALONG THE ATLANTIC AND CARIBBEAN COASTS OF MEXICO
}

\author{
EL GÉNERO HYDROLITHON FOSLIE (CORALLINALES, RHODOPHYTA) \\ EN LA COSTA ATLÁNTICA Y CARIBE DE MÉXICO
}

\author{
Catalina Mendoza-González ${ }^{1}$, Francisco F. Pedroche² \& Luz Elena Mateo-Cid ${ }^{1}$
}

\begin{abstract}
'Departamento de Botánica, Escuela Nacional de Ciencias Biológicas, IPN, Carpio y Plan de Ayala, Col. Santo Tomás, México, D.F. 11 340, México; ${ }^{2}$ Departamento de Hidrobiología, Universidad Autónoma Metropolitana, Unidad Iztapalapa, Apartado Postal 55-535, México, 09340 D.F., and University Herbarium, University of California 1001 VLSB, Berkeley, CA 94720-2465, USA. acmendoz@ipn.mx
\end{abstract}

\section{ABSTRACT}

This paper provides the first monographic account of the genus Hydrolithon Foslie (1909) along the Atlantic and Caribbean coast of Mexico. We found five species of this genus including two new records for this region: H. onkodes (Heydrich) D.Penrose et Woelkerling and H. reinboldii (Weber van Bosse et Foslie) Foslie. The most common species in the study area was H. farinosum (J.V.Lamouroux) D.Penrose et Y.M.Chamberlain. H. onkodes and H. pachydermum (Foslie) J.C.Bailey, J.E.Gabel et D.W.Freshwater were compared with lectotype specimens. All species may be differentiated between them on the basis of the next characteristics: 1) Habit: with or lacking protuberances, free or attached; 2) Thallus construction: monomerous or dimerous; 3) Basal region: unistratose or multistratose; 4) Trichocytes: scattered or in horizontal or vertical rows or large pustulous fields; 5) Pore canal cells: shape. Morphological, anatomical and reproductive accounts are provided, including keys, information on distribution, habitat and nomenclature.

KEYwords: Coralline, Hydrolithon, non-geniculate, taxonomy, distribution.

\section{RESUMEN}

Se realizó el primer informe monográfico sobre el género Hydrolithon Foslie (1909) a lo largo de la costa Atlántica y Caribe de México. Se encontraron 5 especies para este género incluyendo dos nuevos registros para esta región $H$. onkodes (Heydrich) D.Penrose et Woelkerling e H. reinboldii (Weber van Bosse et Foslie) Foslie. La especie más común en el área de estudio fue H. farinosum (J.V.Lamouroux) D.Penrose et Y.M.Chamberlain. H. onkodes and $H$. pachydermum (Foslie) J.C.Bailey, J.E.Gabel et D.W.Freshwater fueron comparados con los lectotipos de ambas especies. Los cinco taxa pueden distinguirse entre sí por las siguientes características: 1) hábito: costrosos lisos, con o sin protuberancias, libres o adheridos; 2) construcción del talo: monómera o dímera; 3) región basal: uniestratosa o multiestratosa; 4) tricocitos: solitarios, en hileras horizontales o verticales o densamente agregados bajo las células epiteliales y la superficie del talo y 5) forma de las células del poro del canal. Se presenta información sobre la morfología, anatomía y estado reproductivo, incluyendo clave, distribución y hábitat de este género.

PaLABras Clave: Corallinaceae, Hydrolithon, no-geniculada, taxonomía, distribución. 
The genus Hydrolithon in the Atlantic coast of México: Mendoza-GonzÁlez, C. ET AL.

\section{INTRODUCTION}

The biodiversity of Coralline red algae (Corallinales, Rhodophyta) along the Atlantic and Caribbean coasts of Mexico is poorly known. These algae are characterized by cell wall impregnated with calcium carbonate, mainly calcite, which gives the thallus a hard, rigid texture (Chamberlain 1983). Coralline algae constitute locally abundant populations of Neogoniolithon Setchell \& Mason, Hydrolithon and Porolithon Foslie from sub-polar to tropical waters (Littler 1972). The best represented nongeniculate forms on the Mexican Atlantic and Caribbean coasts are members of the subfamily Mastophoroideae (Setchell 1943), which includes eight genera (Harvey et al. 2003) and represented on the east coast of Mexico by Spongites, Neogoniolithon and Hydrolithon.

The family Corallinaceae, encompassing those Corallinales whose tetrasporangia produce zonately arranged spores, and whose tetrasporangia and bisporangia are borne in conceptacles that are uniporate and do not produce apical plugs, do not develop beneath multiporate plates or roofs, and are not enclosed individually within calcified sporangial compartments (Harvey et al. 2003). This family includes four subfamilies: Amphiroideae, Corallinoideae, Lithophylloideae and Mastophoroideae, whose genera are mostly calcified, pseudoparenchymatous structure are partly to largely composed of unconsolidated or contiguous filaments; organization is usually dorsiventral and/or radial or isobilateral; construction is monomerous and/or dimerous or diffuse, geniculate and/or non geniculate; spores are zonately arranged (Harvey et al. 2003, Guiry \& Guiry 2007). The Subfamily Mastophoroideae contains genera which lack genicula; cells of adjacent filaments are linked principally by cellfusions, secondary pit-connections are absent or rare; tetra- bisporangial conceptacles are uniporate and lack apical plugs. Within the Mastophoroideae, the genus Hydrolithon comprises non-geniculate algae with a dorsiventral organization of dimerous and/or monomerous construction (Penrose \& Woelkerling 1988), but lack a ventral layer of palisade cells; cells of adjacent filaments are joined by cell fusions and do not have haustoria; trichocytes present or absent, if present appearing in section single, in horizontal fields, horizontal rows, and vertical rows (Penrose 1996). Tetrasporangialbisporangial conceptacle pore canals are lined by cells that are oriented more or less perpendicularly to the roof surface and do not protrude laterally into the pore canal.

The genera Hydrolithon and Neogoniolithon are both important components of Mexican Caribbean coral reefs (Huerta et al. 1987, Mendoza-González \& Mateo Cid 1992, Ortega et al. 2001, MateoCid \& Pedroche 2004). In addition, Hydrolithon is very common on the majority of rocky shores of Atlantic Mexico. However, in spite of their abundance, representatives of this genus from Mexico have received little attention, and no previously description of Hydrolithon from the eastern coast from Mexico has been found, thus have not been critically examined. Only three species, H. boergesenii (Foslie) Foslie, H. farinosum (J.V.Lamouroux) D.Penrose et Y.M.Chamberlain and H. improcerum (Foslie et Howe) Foslie have been reported from the Caribbean and Atlantic coasts of Mexico (Ortega et al. 2001). The aims of this paper are to provide morphological, anatomical and reproductive accounts of Hydrolithon's taxa, in order to identify species in a modern context. Distinctive field characters as well as pertinent photographs are provided for each species. Data on distribution of the species along the Atlantic and Caribbean coast of Mexico is included.

\section{MATERIALS AND METHODS}

The lectotype specimens of Hydrolithon onkodes (Heydrich) D.Penrose et Woelkerling (Porolithon onkodes (Heydrich) Foslie) and H. pachydermum (Foslie) J.C.Bailey, J.E.Gabel et D.W.Freshwater (Lithophyllum onkodes f. pachydermum Foslie) were borrowed from TRH (Department of Botany, Museum of Natural History and Archeology, University of Trondheim, Norway). Specimens of Hydrolithon were borrowed from ENCB (Department of Botany, National School at Biological Sciences, Mexico, D.F.) this samples were collected for different people from 1964 to 2001. Also, specimens of Hydrolithon were found in samples of general collections of common corallines collected by reef-walking or snorkeling at Banco Chinchorro, Cozumel and Mujeres islands, El Zarzal, Playa del Carmen and Akumal (Quintana Roo); Alacrán Reef (Yucatán); and La Blanquilla, 
Gayana Bot. 66(2), 2009

Verde and Enmedio islands, Punta Morro and Villa Rica (Veracruz) (Fig. 1). Samples were preserved in $5 \%$ formalin/seawater. Preserved specimens were decalcified with $0.6 \mathrm{M} \mathrm{HNO}_{3}$ and dehydrated with ethyl alcohol. Small segments were embedded in paraffin and sectioned at 9-12 $\mu \mathrm{m}$ thick with a manual microtome. Sections were then, fixed on slides with Riuter's adhesive (Martoja \& MartojaPierson 1970), and stained with aniline blue and hematoxilin-eosine for anatomical observations and measurements.

The classification system of Penrose \& Chamberlain (1993), Penrose (1996); Chamberlain (1994), Keats \& Chamberlain (1994) and Harvey et al. (2003) are used throughout this paper. In cell measurements length denotes the distance between primary pit connections whereas diameter denotes the maximum width of the cell lumen at right angles to this. Conceptacle measurements follow the system of Adey \& Adey (1973). Descriptive terminology follows Woelkerling (1988) and Penrose (1996). Growth-forms terminology follows Woelkerling et al. (1993). Typification data follow Woelkerling (1993). Pertinent remarks about the morphology, anatomy, detailed descriptive accounts, and specimens examined and distributions are provided for each species. In this study we made observations on a total of 100 specimens are housed at herbarium of the Escuela Nacional de Ciencias Biológicas (ENCB).

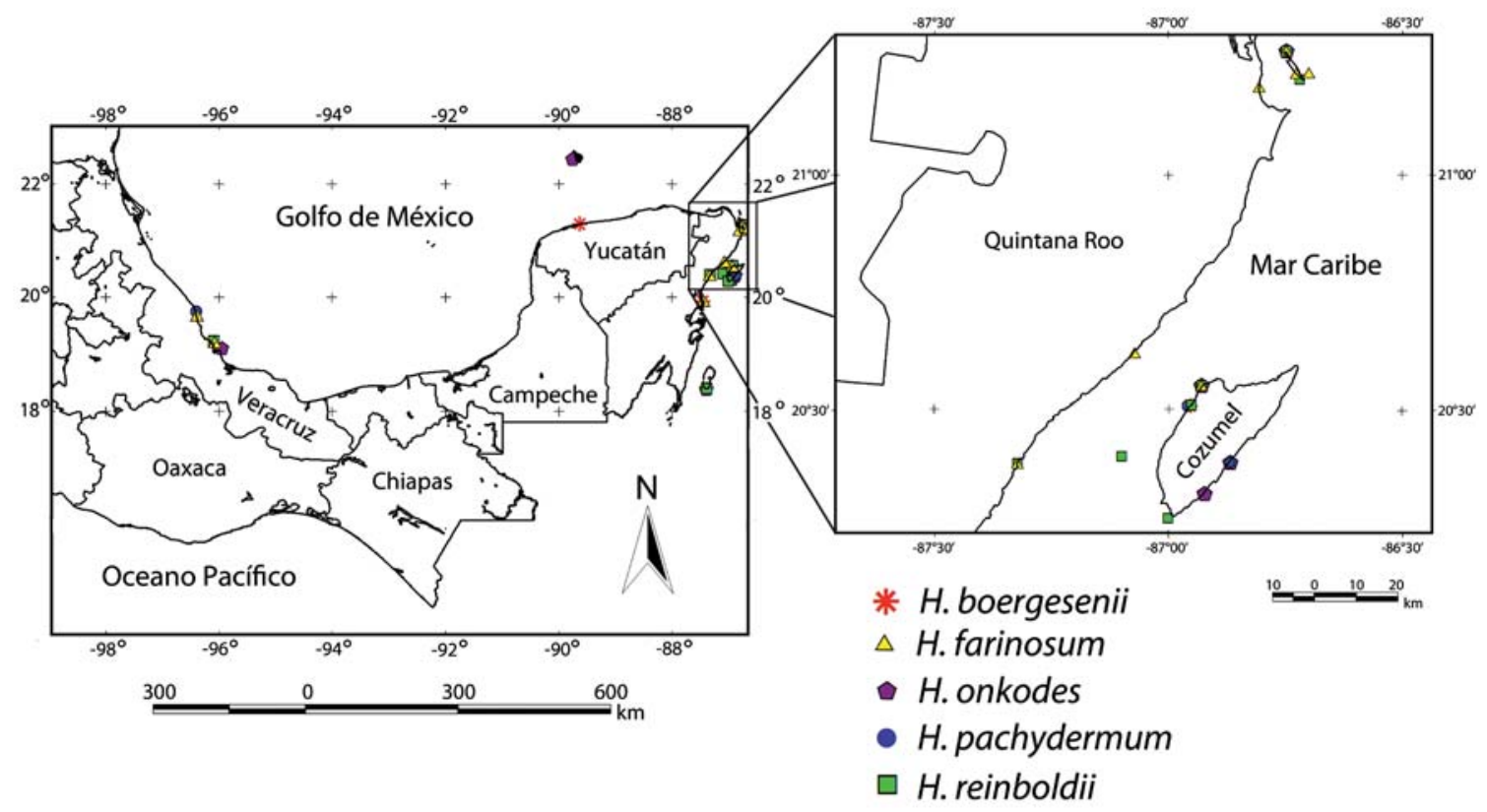

FIGURE 1. Location of the study sites and distribution of Hydrolithon's species in the study area.

FIGURA 1. Ubicación del área de estudio y distribución de las especies de Hydrolithon. 


\section{RESULTS}

Hydrolithon Foslie (1909:55) emend Penrose et Woelkerling (1992: 87)
Five species representing the genus Hydrolithon were encountered during the present study, two of which are new record from the Atlantic and Caribbean coasts of Mexico.

\section{Key to the Mexican Hydrolithon}

1. Plants only epiphytic

H. farinosum

1. Plants mainly epilithic or epizoic

2. Thallus entirely dimerous; trichocytes most often occurring singly, occasionally in pairs and/or small horizontal or vertical rows

2. Thallus mostly monomerous; trichocytes most often occurring in large horizontal pustulate fields without any vegetative filaments between the individual trichocytes.....

3. Cells of erect filaments strongly horizontally arranged

3. Cells of erect filaments not strongly horizontally arranged.

H. boergesenii

4. Plants smooth, warty or lumpy, commonly with 3-4 layers of epithallial cells and conceptacle chamber elliptic.....

4. Plants with small protuberances, commonly with a one layer of epithallial cells and conceptacle chamber orbicular.

DESCRIPTION OF THE SPECIES

1. Hydrolithon boergesenii (Foslie) Foslie, K. Norske Vidensk. Selsk. Skr. 2: 56. 1909.

Basionym: Goniolithon boergesenii Foslie, K. Norske Vidensk. Selsk. Biol. Skr. 2: 19-21. 1901.

Synonyms: Lithophyllum boergesenii (Foslie) Foslie, K. Norske Vidensk. Selsk. Biol. Skr. 2: 5. 1901; , K. Norske Vidensk. Selsk. Biol. Skr. 2: 19-21.1901; Porolithon boergesenii (Foslie) M.Lemoine, in Børgesen. Dansk. Bot. Ark. 3: 178. 1917; Spongites boergesenii (Foslie) Woelkerling, Dreckmann Hidrobiológica 1(2): 35. 1991.

Type locality: St. Croix, US Virgin Islands.

Habit and vegetative Structure. Thallus attached to the substratum ventrally by cell adhesion, surface with warty protuberances (Fig. 2a), and 420 $\mu \mathrm{m}-2 \mathrm{~mm}$ thick. Pseudoparenchymatous; thallus construction dimerous, basal region unistratose with ventral cells vertically elongated, $6-15 \mu \mathrm{m}$ in diameter and 12-30 $\mu \mathrm{m}$ high, others square, 9 $\mu \mathrm{m}$ in diameter; fusion cells $9-18 \mu \mathrm{m}$ in diameter and $12-30 \mu \mathrm{m}$ high; epithallial cells unistratose or bistratose with oblong cells 3-6 $\mu \mathrm{m}$ high and 6-12 $\mu \mathrm{m}$ diameter; dorsal region composed of filaments becoming oriented perpendicularly to thallus surface with rounded and square cells 9-15 $\mu \mathrm{m}$ diameter, depressed-globose, $4 \mu \mathrm{m}$ high and $6 \mu \mathrm{m}$ diameter with plasmodesmata and several fusions (Fig. 2b). Trichocytes occurred singly and scattered in dorsal region, in small horizontal with vegetative cells scattered between them and vertical rows, $15-26 \mu \mathrm{m}$ in diameter and 21-39 $\mu \mathrm{m}$ long, some of these cells have a prolonged wall on top like a bell (Fig. 2c). Growing by oblong or triangular meristhematic initial cell $18-21 \mu \mathrm{m}$ in diameter and 15-36 $\mu \mathrm{m}$ tall.

Reproductive Structures. Tetra/bisporangial thallus 1-2 mm thick with uniporate, protruding, domoid conceptacles, others buried in the pseudoparenchymatous tissue, several or scattered on the thallus surface, approximately 50/24 conceptacles per $\mathrm{mm}^{2}$ (Fig. 2d); tetra/ bisporangial chambers lacking a central columella, ovoid or elliptical, 174-216/81-165 $\mu \mathrm{m}$ in diameter and 81-96 $\mu \mathrm{m}$ high, roof of conceptacle with 3 or more cell layers and $24 \mu \mathrm{m}$ high, pore canals lined by cells oriented more or less perpendicular to the thallus surface, not protruding into the canal, cells concave, 6-7.5 $\mu \mathrm{m}$ in diameter and 12-28/9-30 $\mu \mathrm{m}$ high (Figs. $2 \mathrm{e}, \mathrm{f})$; tetrasporangium usually $25-42 \mu \mathrm{m}$ in diameter and $63 \mu \mathrm{m}$ high. Bisporangium 45$50 \mu \mathrm{m}$ diameter and 77- $90 \mu \mathrm{m}$ high (Fig. $2 \mathrm{~g}$ ). Gametangial thalli not observed. 

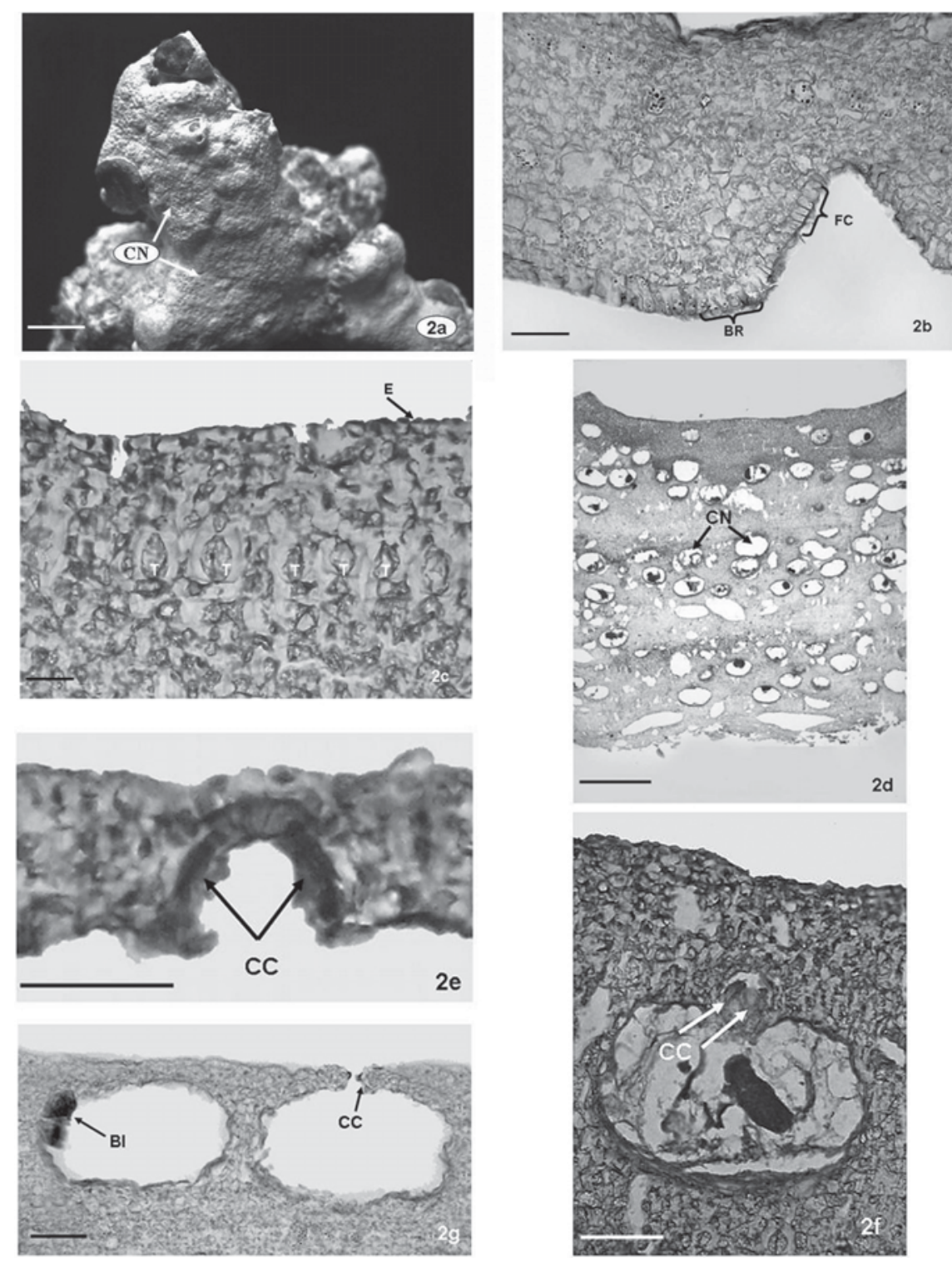

Figure 2. Hydrolithon boergesenii, El Zarzal, Quintana Roo, 17-V-1998 (ENCB 17185). a. Habit of a plant encrusting dead coral. Conceptacles $(\mathrm{CN})$ are highlighted by arrows. Scale: $1.2 \mathrm{~cm}$. b. A dimerous thallus showing a unistratose basal region (BR). Note also the cell fusions (FC) between cells of adjacent basal filaments. Scale: $44 \mu \mathrm{m}$. c. Section through cortical region of the thallus showing trichocytes $(\mathrm{T})$ in a horizontal rows and a single layer so epithallial cells (E). Scale: $26 \mu \mathrm{m}$. d. Longitudinal view of the thallus showing several buried conceptacles (CN).Scale: 288 $\mu \mathrm{m}$. e. Tetrasporangial conceptacle showing pore canal lined by enlarged cells (CC). Scale: $32 \mu \mathrm{m}$. f. Pore of buried tetrasporangial conceptacle showing enlarged pore canal cells (CC). Scale: $63 \mu \mathrm{m}$. g. Bisporangial conceptacle showing pore canal cells (CC) and a single bisporangium (BI). Scale: $100 \mu \mathrm{m}$.

FIgURA 2. Hydrolithon boergesenii, El Zarzal, Quintana Roo, 17-V-1988 (ENCB 17185). a. Talo incrustante en coral muerto. Conceptáculos $(\mathrm{CN})$ indicados con flecha. Escala: $1,2 \mathrm{~cm}$. b. Talo dímero mostrando una región basal uniestratosa (BR). Observe las fusiones celulares (FC) entre las células de filamentos basales adyacentes. Escala: 44 $\mu \mathrm{m}$. c. Sección transversal de la región cortical, mostrando tricocitos $(\mathrm{T})$ en hileras horizontales y una capa de células epiteliales (E). Escala: $26 \mu \mathrm{m}$. d. Corte longitudinal del talo mostrando numerosos conceptáculos (CN). Escala: 288 $\mu \mathrm{m}$. e. Conceptáculo tetrasporangial mostrando el poro delineado por células alargadas del canal (CC). Escala: $32 \mu \mathrm{m}$. f. Poro del conceptáculo tetrasporangial, mostrando las células alargadas del canal (CC). Escala: $63 \mu \mathrm{m}$. g. Conceptáculo bisporangial, células del canal (CC) y un bisporangio (BI). Escala: $100 \mu \mathrm{m}$. 
The genus Hydrolithon in the Atlantic coast of México: Mendoza-GonzÁlez, C. ET AL.

SPecimens eXAmined: MEXICO, Quintana Roo, Cozumel Island, south deck $\left(20^{\circ} 30^{\prime} 32^{\prime} \mathrm{N}\right.$, 86 57'07'W), 10-IX-1985, C. Mendoza \& L.E. Mateo s.n. (ENCB 17186); El Zarzal (1955'47.7'N, 87²6’32.7'W), 18-V-1998, C. Mendoza \& L. E. Mateo s.n. (ENCB 17185), Yucatán: Arrecife Alacranes, Pérez Island

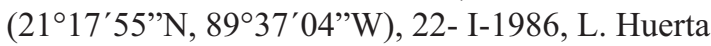
s.n. (ENCB 17198).

HАвітAт: Epiphytic on Lithoporella sp.: epilithic on rocks and epizoic on coral skeletons; intertidal.

REMARKS: The vegetative and reproductive structure of these plants is clearly similar to that described as Porolithon boergesenii by Lemoine (in Børgesen 1917) and Masaki (1968) and as Goniolithon boergesenii by Taylor (1960). In the other hand, Lemoine (1917) and Taylor (1960) describe tetrasporangial conceptacle chamber diameters of $300-400 \mu \mathrm{m}$ without indicating whether these were inner or external dimensions. Our specimens have tetra/bisporangial conceptacle chambers 174-216 $\mu \mathrm{m}$ in diameter and 81-96 $\mu \mathrm{m}$ high. Pore canal cells of tetra/bisporangial conceptacles appear to arise from filaments interspersed amongst sporangial initials and are concave or reniform, and are 6-8 $\mu \mathrm{m}$ diameter, 12-24 $\mu \mathrm{m}$ high.

It is primarily a tropical western Atlantic species, but also reported from the African Atlantic and Japan (Guiry \& Guiry 2007) and the Caribbean Sea (John et al. 1979).

2. Hydrolithon farinosum (J.V.Lamouroux) D.Penrose \& Y.M.Chamberlain, Phycologia 32: 295-303. 1993. Figs. 1-19.

Basionym: Melobesia farinosa J.V.Lamouroux, Poisson: Caen. 315. 1816.

Synonyms: Fosliella farinosa (J.V.Lamouroux) M.A.Howe. The Bahama Flora, p. 587, 1920; Fosliella cruciata G.Bressan, D.Miniati-Radin \& L.Smundin, Giorn. Bot. Ital. 111: 27. 1977.

Type locality: The Mediterranean Sea.

Habit AND VEgETATIVE STRUCTURE. Epiphytic, covering up to $10 \mathrm{~cm}$ of host (Fig. 3a), thallus attached to the host ventrally by cell adhesion, dorsal surface flattened (Figs. 3b), lacking protuberances; thallus pseudoparenchymatous, thin 20-90 $\mu \mathrm{m}$ diameter, cells of adjacent filaments connected laterally by fusions, secondary pit-connections not seen; thallus construction dimerous with 2-5 layers of cells (Fig. 3c); epithallial cells unistratose with oblong cells 3-6 $\mu \mathrm{m}$ high and 6-18 $\mu \mathrm{m}$ diameter; growth by marginal initial cells, reniform, obovoid or rounded 12-27 $\mu \mathrm{m}$ high and 24-30 $\mu \mathrm{m}$ diameter; basal region unistratose with square cells $15 \mu \mathrm{m}$ diameter or rectangular 12-30 $\mu \mathrm{m}$ high and 9-21 $\mu \mathrm{m}$ diameter; dorsal region composed of filaments that become oriented perpendicularly to the thallus surface, unistratose or multistratose, cells square, 12 $\mu \mathrm{m}$ in diameter, some of them vertically elongate, 6-15 $\mu \mathrm{m}$ diameter and 9-33 $\mu \mathrm{m}$ high, oblong, 15-27 $\mu \mathrm{m}$ in diameter and 6-12 $\mu \mathrm{m}$ high, with numerous cell-fusions; with few or many cell fusions in the dorsal and basal regions, 12-30 $\mu \mathrm{m}$ diameter, others 9-12 $\mu \mathrm{m}$ high and 15-21 $\mu \mathrm{m}$ diameter; trichocytes or megacells occur singly and in small horizontal rows with vegetative cells scattered between them, cells 12-36 $\mu \mathrm{m}$ diameter and 24-42 $\mu \mathrm{m}$ high.

Reproductive structures: Tetrasporangial plants 20-90 $\mu \mathrm{m}$ thick, conceptacles up to $180 \mu \mathrm{m}$ in diameter, uniporate, protruding, domoid, approximately 50 per $\mathrm{mm}^{2}$; pore appears deeply sunken when open; tetrasporangial chambers elliptical, 31-100 $\mu \mathrm{m}$ high and 100-300 $\mu \mathrm{m}$ diameter, and with a central columella; roof of 2-3 cell layers $15-45 \mu \mathrm{m}$ high, the chamber floor raised centrally; pore canal cells elongated and orientated more or less perpendicular to the thallus surface and does not protrude into the pore canal, pore canal shape convex or triangular, 3-12 $\mu \mathrm{m}$ diameter and 15-33 $\mu \mathrm{m}$ high. Tetrasporangium 20-57 $\mu \mathrm{m}$ diameter and 31-63 $\mu \mathrm{m}$ high. Bisporangial plants not observed. Carposporangial plants 20-75 $\mu \mathrm{m}$ thick; conceptacles uniporate, protruding, domoid, densely packed, approximately 100 per $\mathrm{mm}^{2}$; carposporangial chambers have the same elliptical shape as tetrasporangial conceptacles, 76-207 $\mu \mathrm{m}$ in diameter and 40-107 $\mu \mathrm{m}$ high, roof conceptacle with 3-6 layers cells, roof 10-21 $\mu \mathrm{m}$ high, lined by elongated cells angularly oriented or convex $4 \mu \mathrm{m}$ diameter and $10 \mu \mathrm{m}$ high, or triangular, $2 \mu \mathrm{m}$ in diameter and $27 \mu \mathrm{m}$ high (Fig. 3d); conceptacles with lump of mucilage obstructing pore canals, carposporangia 24-42 $\mu \mathrm{m}$ in diameter and 25$50 \mu \mathrm{m}$ high (Fig. 3e). Gonimoblast filaments borne from the margins of the fusion cell (Fig. 2d). Spermatangial plants 21-60 $\mu \mathrm{m}$ thick with 

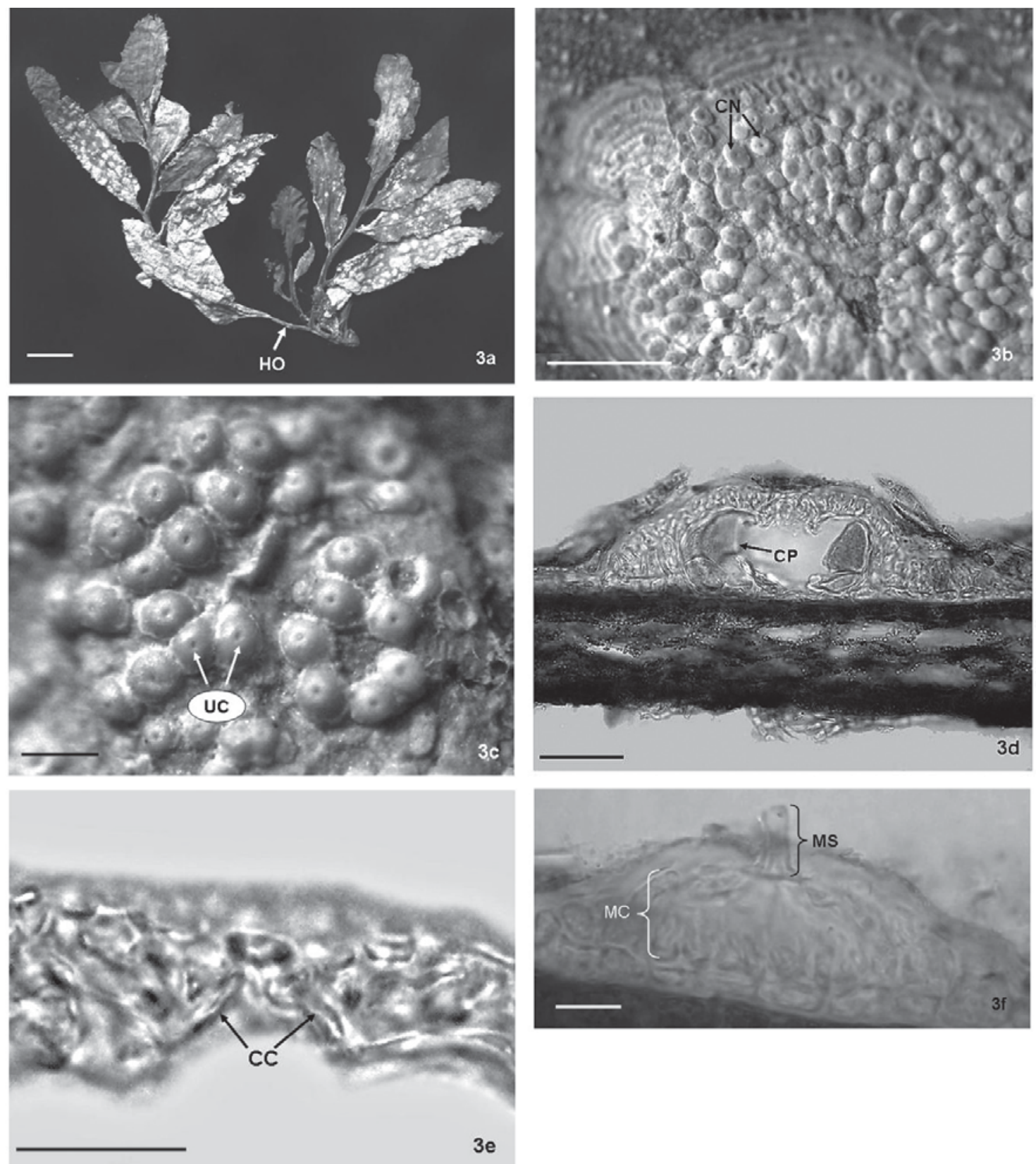

FIGURE 3. Hydrolithon farinosum, Villa Rica, Veracruz, 14-XI-1994 (ENCB 17 158). a. Thallus epiphytic on Sargassum (HO) host. Scale: $7 \mathrm{~mm}$. b. Thallus surface showing congested uniporate conceptacles $(\mathrm{CN})$. Scale: $1.4 \mathrm{~mm}$. c. Close-up of thallus surface showing uniporate conceptacles (UC). Scale: $330 \mu \mathrm{m}$. d. Section of the thallus showing a carposporangial conceptacle bearing peripherally arranged gonimoblast filaments terminating in carpospores (CP). Scale: $55.5 \mu \mathrm{m}$. e. Pore of tetrasporangial conceptacle lined by enlarged pore canal cells (CC). Scale: $24 \mu \mathrm{m}$. f. Immature spermatangial conceptacle (MC) with mucilaginous spout (MS). Scale $26 \mu \mathrm{m}$.

Figura 3. Hydrolithon farinosum, Villa Rica, Veracruz, 14-XI-1994 (ENCB 17 158). a. Talo epífito en Sargassum (HO). Escala: $7 \mathrm{~mm}$. b. Superficie del talo, mostrando un denso agregado de conceptáculos uniporados (CN). Escala: $1.4 \mathrm{~mm}$. c. Detalle de la superficie del talo mostrando conceptáculos (UC). Escala: $330 \mu \mathrm{m}$. d. Sección del talo mostrando el conceptáculo carposporangial con filamentos gonimoblásticos que terminan en carposporas (CP). Escala: $55.5 \mu \mathrm{m}$. e. Poro del conceptáculo tetrasporangial delineado por células alargadas del canal del poro (CC). Escala: $24 \mu \mathrm{m}$. f. Conceptáculo espermatangial inmaduro (MC) con tapón mucilaginoso (MS) Escala: $26 \mu \mathrm{m}$. 
The genus Hydrolithon in the Atlantic coast of México: Mendoza-GonzÁlez, C. ET AL.

the same structure as the tetrasporangial plants; uniporate conceptacles protrude above thallus surface; conceptacles scattered and small, domoid, approximately $14-20$ conceptacles per $\mathrm{mm}^{2}$; roof 3 cell layers, pore $6-10 \mu \mathrm{m}$ diameter with a large mucilaginous spout $6-12 \mu \mathrm{m}$ high; orbicular or elliptical, 48-73 $\mu \mathrm{m}$ diameter and 11-40 $\mu \mathrm{m}$ high, spermatangia are singled and restricted only at conceptacle floor; pore canal cells long and angularly oriented, $24 \mu \mathrm{m}$ diameter (Fig. 3f).

SPECIMENS EXAMINED. MEXICO, Veracruz, Villa Rica (1940’33'N, 96²3'32”W), 14-XI-1994, C. Mendoza \& L.E. Mateo s.n. (ENCB 17158); Verde Island $\left(19^{\circ} 12^{\prime} 13^{\prime \prime} \mathrm{N}, 96^{\circ} 04^{\prime} 23^{\prime \prime} \mathrm{W}\right), 13-$ XI-1986, L.E. Mateo Cid s.n. (ENCB 7922), 14V-1984, C. Mendoza \& L.E. Mateo s.n. (ENCB 6871); Quintana Roo, Cozumel Island, Playa San Juan (20³3'02'N, 8655'49'W), 4-VI-1998, C. Mendoza \& L.E. Mateo s.n. (ENCB 6868), Punta Norte, Mujeres Island $\left(21^{\circ} 15^{\prime} 52.5^{\prime} \mathrm{N}\right.$, 8644'56”W), 13-VIII-1997 C. Mendoza \& L.E. Mateo s.n. (ENCB 17156), 13-X-1983, L. Huerta, C. Mendoza, L.E. Mateo \& A. Cisneros s.n. (ENCB $10260)$, east zone, Mujeres Island $\left(21^{\circ} 13.5^{\circ} 0^{\prime} \mathrm{N}\right.$, $\left.86^{\circ} 42.5^{\prime} 0^{\prime \prime} \mathrm{W}\right), 2-\mathrm{III}-1985$, C. Mendoza \& L.E. Mateo s.n. (ENCB 7876), Playa Lancheros, Mujeres Island $\left(21^{\circ} 12^{\prime} 59.4^{\prime} \mathrm{N}, 86^{\circ} 43^{\prime} 41^{\prime \prime} \mathrm{W}\right), 1$ II-1984, L.E. Mateo \& C. Mendoza s.n. (ENCB

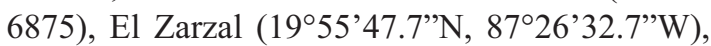
19-V-1998, L.E. Mateo \& C. Mendoza s.n. (ENCB 17141), Puerto Juárez, Cancún (2111'15.3”N, 8648'25.6”W), 1-III-1985, L.E. Mateo \& L. Huerta s.n. (ENCB 10255), Akumal (20²3'9.8'N, 87¹9'21.6”W), 24-XII-1992, L. Huerta s.n. (ENCB 17142), Playa del Carmen $\left(20^{\circ} 37^{\prime} 17^{\prime} \mathrm{N}\right.$, 8704'19”W), 1-XI-1984, C. Mendoza \& L.E. Mateo s.n. (ENCB 13219).

HАвітAт:Always epiphytic on Thalassia testudinum, Sargassum sp. and Dictyota sp., intertidal.

REMARKs. All specimens were found growing on Sargassum, Dictyota or Thallassia, and associated with species of the genera Pneophyllum, Peyssonnelia, Taenioma, Calothrix and other cyanobacteria. Our specimens are in general agreement with the dimensions reported for Australian plants by Penrose \& Chamberlain (1993), who provided a detailed description of $H$. farinosum. These authors mentioned that gametangial plants are monoecious with spermatangial and carpogonial conceptacles occurring on the same plant. They also did not see bisporangial conceptacles. The same authors described the pore canals of tetrasporangial conceptacles as bearing elongate cells. Our plants are, however, dioecious with carpogonial and spermatangial conceptacles occurring on separate thalli.

$H$. farinosum is a cosmopolitan species and is the most common species in the eastern coast of Mexico.

3. Hydrolithon onkodes (Heydrich) D.Penrose \& Woelkerling, Phycologia 31: 834, figs 4, 5. 1992.

Basionym: Lithothamnion onkodes Heydrich, Bibl. Bot. 41: 6, pl. 1. 1897.

Synonyms: Goniolithon onkodes (Heydrich) Foslie, K. Norske Vidensk. Selsk. Skr. 2: 8. 1898; Lithophyllum onkodes (Heydrich) Heydrich, Bot. Jb. 28: 529-545, pl. 11. 1901; Porolithon onkodes (Heydrich) Foslie, K. Norske Vidensk. Selsk. Skr. 2: 57. 1909; Spongites onkodes (Heydrich) D. Penrose et Woelkerling, Phycologia 26: 159, figs. 10-14. 1988 (See also Penrose 1990: 134, figs 44-49).

Lectotype: TRH, A26-1494! (Designated by Adey et al. 1982: 9).

Type locality: Tami I., north-west edge of Huon Gulf, New Guinea (Heydrich 97, Bambler, 1894).

Habit AND VEgEtATIVE STRUCTURE. Thallus encrusting, attached to the substratum ventrally by cell adhesion, without rhizoids, with a more or less flattened dorsal surface (Fig. 4a) or with small protuberances (Fig. 4b), $200 \mu \mathrm{m}-4 \mathrm{~mm}$ thick; construction mostly monomerous (Fig. 4c); but also dimerous; dimerous portions consisting of a single ventral layer of non palisade cells, and erect multicellular simple or branched filaments; monomerous portions consisting of a multiaxial system of branched filaments (basal region) that collectively contribute to a ventrally or centrally situated core, and a peripheral region where portions of core filaments or their derivatives curve outwards towards the thallus surface, the ventral cells are oblong or rectangular 4-13 $\mu \mathrm{m}$ high and 9-30 $\mu \mathrm{m}$ diameter, the cortical cells are square or rounded 12 $20 \mu \mathrm{m}$ diameter globose, $6-9 \mu \mathrm{m}$ in diameter with several fusions and vertically long cells $8-18 \mu \mathrm{m}$ diameter, 18-24 $\mu \mathrm{m}$ high; epithallial cells unistratose with rounded cells $6-9 \mu \mathrm{m}$ in diameter, or bistratose 

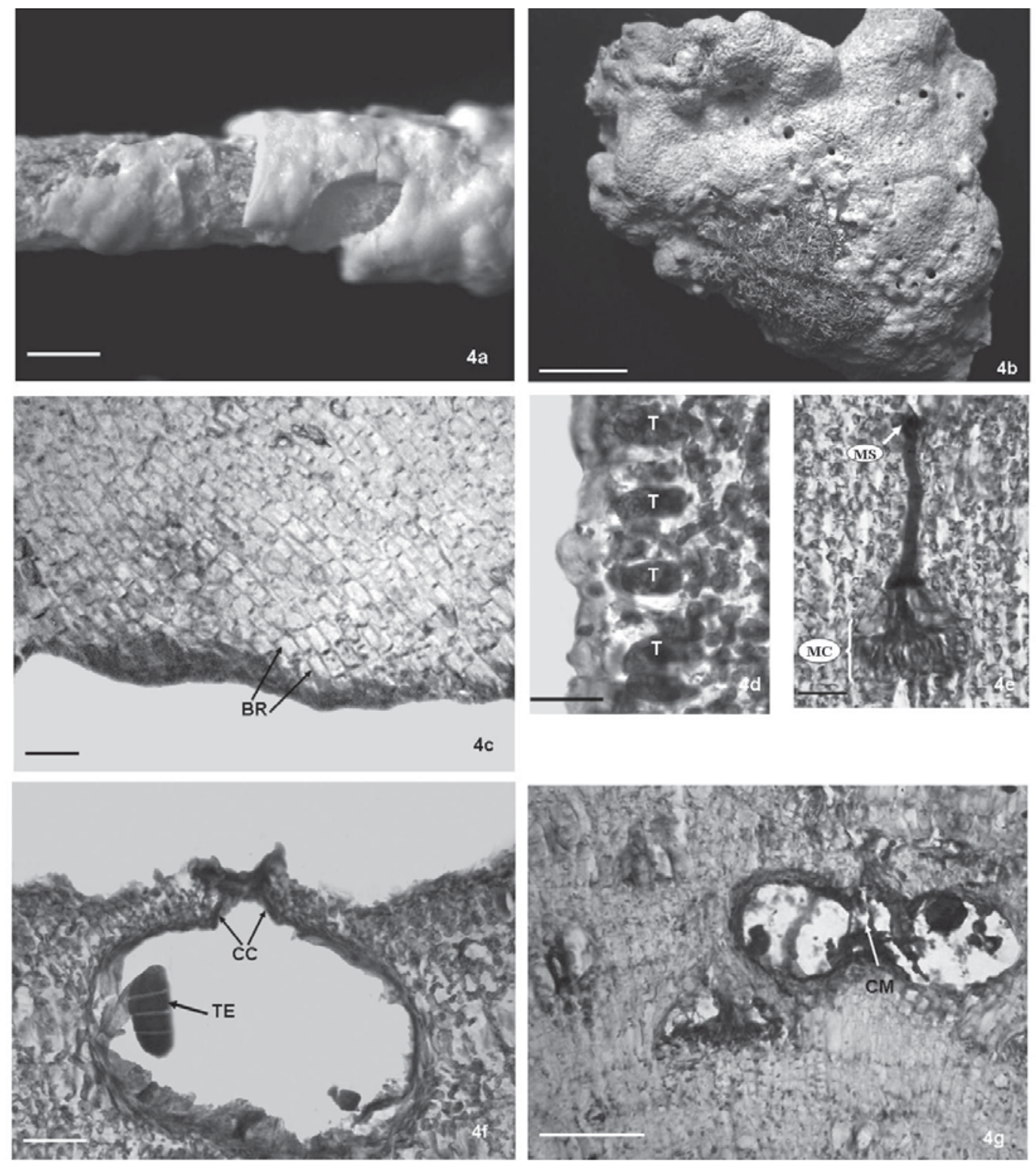

Figure 4. Hydrolithon onkodes, Playa Azul, Cozumel Island, Quintana Roo, 22-V-1993 (ENCB 17184 ○ and $ð$ ); Playa San Juan, Cozumel Island 27-II-1985 (ENCB 17181 tetrasporangial). a. Habit of gamentangial plant. Scale: $2 \mathrm{~mm}$. b. Habit of tetrasporangial plant. Scale: $1.1 \mathrm{~cm}$. c. Section through a monomerous thallus showing a multistratose basal region (BR) with downward curving filaments. Scale: $28 \mu \mathrm{m}$. d. Trichocytes in horizontal rows (T). Scale: $21 \mu \mathrm{m}$. e. A buried spermatangial conceptacle (MC) with mucilaginous spout (MS). Scale: $67 \mu \mathrm{m}$. f. A tetrasporangial conceptacle bearing a single tetrasporangium (TE) and showing a pore canal lined by enlarged cells (CC). Scale: $44 \mu \mathrm{m}$. g. A buried tetrasporangial conceptacle with a central columella (CM). Scale: $85 \mu \mathrm{m}$.

Figura 4. Hydrolithon onkodes, Playa Azul, Isla Cozumel, Quintana Roo, 22-V-1993 (ENCB 17184 talo gametangial); Playa San Juan, Isla Cozumel 27-II-1985 (ENCB 17181 talo tetrasporangial). a. Hábito del talo gametangial. Escala: 2 $\mathrm{mm}$. b. Hábito del talo tetrasporangial. Escala: $1,1 \mathrm{~cm}$. c. Corte longitudinal del talo monómero que muestra una región basal multiestratosa (BR) con filamentos que siguen el contorno del sustrato. Escala: $28 \mu \mathrm{m}$. d. Tricocitos en hileras horizontales (T). Escala: $21 \mu \mathrm{m}$. e. Agregado de conceptáculos espermatangiales (MC) con tapón mucilaginoso (MS). Escala: $67 \mu \mathrm{m}$. f. Conceptáculo tetrasporangial con un tetrasporangio (TE) mostrando el poro del canal delineado por células alargadas (CC). Escala: $44 \mu \mathrm{m}$. g. Conceptáculo tetrasporangial con columella central (CM) Escala: $85 \mu \mathrm{m}$. 
with square or rectangular cells 3-9 $\mu \mathrm{m}$ high and 5$8 \mu \mathrm{m}$ diameter; the peripheral region, with rounded or square cells $15-21 \mu \mathrm{m}$ diameter, rectangular cells 9-12 $\mu \mathrm{m}$ high,15-21 $\mu \mathrm{m}$ diameter, polygonal cells 9-12 $\mu \mathrm{m}$ tall and 6-12 $\mu \mathrm{m}$ diameter; near the basal region, several cells have fusions; trichocytes occur in vertical and horizontal rows (Fig. 4d), individual trichocytes 12-24 $\mu \mathrm{m}$ diameter and 18-33 $\mu \mathrm{m}$ high; growth by oblong initial cells $12-21 \mu \mathrm{m}$ diameter and 21-30 $\mu \mathrm{m}$ high.

REPRODUCTIVE STRUCTURES. Tetra/bisporangial thallus 216/4000 $\mu \mathrm{m}$ thick, the conceptacles domoid, protruding or flush from thallus surface approximately 10 per $\mathrm{mm}^{2}$, others buried in the pseudoparenchymatous tissue; tetra/bisporangial chambers elliptical and rounded 36-165/ 36-180 $\mu \mathrm{m}$ high, 186-231/141-255 $\mu \mathrm{m}$ diameter, roof of conceptacle $4-8$ cells thick and $39 \mu \mathrm{m}$ tall, pore canals lined by cells oriented perpendicular to the thallus surface, triangular, 12-24 $\mu \mathrm{m}$ diameter, 15$36 \mu \mathrm{m}$ tall, or convex 9-18 $\mu \mathrm{m}$ diameter and 30-33 $\mu \mathrm{m}$ tall; tetrasporangium 16-51 $\mu \mathrm{m}$ diameter and 36 $72 \mu \mathrm{m}$ high, with or without a mucilage plug in the conceptacle pore and with a central columella(Fig. 4f). Bisporangium usually 21-75 $\mu \mathrm{m}$ diameter and 41-95 $\mu \mathrm{m}$ tall. Gametangial plants monoecious; carpogonia and spermatangia produced on the same thallus, but in separate conceptacles, thallus $470 \mu \mathrm{m}-1 \mathrm{~mm}$ thick with the same vegetative structure as the tetra/bisporangial plants; carposporangial conceptacles uniporate, buried in the pseudoparenchymatous tissue or protruding, apiculate or not, scattered, approximately 9 per $\mathrm{mm}^{2}$; elliptical chambers $114-140 \mu \mathrm{m}$ in diameter and 30$60 \mu \mathrm{m}$ high. Mature carposporophytes composed of a large central fusion cell and gonimoblast filaments bearing terminal carposporangia, roof of conceptacle 4-8 layers cells and $30 \mu \mathrm{m}$ high, pore canals lined by cells oriented more or less perpendicular to the surface thallus and not protruding into de canal, cells form angular long or concaves $6 \mu \mathrm{m}$ diameter and $21 \mu \mathrm{m}$ tall with carposporangial plug (Fig. $4 \mathrm{~g}$ ), carposporangia $21 \mu \mathrm{m}$ diameter and 27-33 $\mu \mathrm{m}$ tall. Spermatangial conceptacles on the same thallus with uniporate buried, or protruding above, or flush with surrounding thallus surface; conceptacles scattered approximately 10 per $\mathrm{mm}^{2}$; elliptical chambers $67 \mu \mathrm{m}$ diameter and $30 \mu \mathrm{m}$ tall, roof of conceptacle $24 \mu \mathrm{m}$ high spermatangial filaments unbranched arising from the floor of male conceptacle chambers (Fig. 4e).
SPECIMENS EXAMINED: MEXICO, Veracruz, Enmedio Island $\left(19^{\circ} 06^{\prime} 01^{\prime \prime} \mathrm{N}, 95^{\circ} 56^{\prime} 19.5^{\prime} \mathrm{W}\right)$, 5-VI-2001, C. Galicia s.n. (ENCB 17176), Yucatán, Arrecife Alacrán, Desertora island, 15-X-1985, L. Huerta, L.E. Mateo \& E. Hidalgo s.n. (ENCB 17169 ), Quintana Roo, Cozumel Island, Playa San Juan (20³3'02'N, 8655'49’W), 27-II-1985, C. Mendoza \& L.E. Mateo s.n. (ENCB 17181), El Mirador (20¹9'15’N, 86 55'27'’W), 7-VI-1985, L.E. Mateo \& C. Mendoza s.n. (ENCB 17182), Chen Río $\left(20^{\circ} 23^{\prime} 18^{\prime}\right.$ 'N, 8652'08’W), 07-VI-1985, C. Mendoza \& L.E. Mateo s.n. (ENCB 17183), Playa Azul (20³3'02'N, 8655'49'W), 22-V-1993, C. Mendoza, L.E. Mateo, L. Huerta \& C. Galicia s.n. (ENCB 17184), Punta Norte, Mujeres Island $\left(21^{\circ} 15^{\prime} 52.5^{\prime}\right.$ 'N , 86 $44^{\circ}$ '56'W), 12-VI-1987, C. Mendoza \& L.E. Mateo s.n. (ENCB 17174), Banco Chinchorro, Cayo Lobos (18 23'11'N, 87²2'53”W), 19-VI-1984, L. Huerta \&. L.E. Mateo s.n. (ENCB 17180).

НАвІтAт: Epilithic on rocks, and encrusting dead coral skeletons, intertidal and subtidal.

REMARKS: On the basis of examination of the lectotype of Hydrolithon onkodes from TRH, We concluded that the Mexican specimens of $H$. onkodes agree well with the lectotype. Our observations confirm those reported by Penrose \& Woelkerling (1988). Measurements of somatic cells (inclusive trichocytes) in all Mexican specimens that we revised are largely concordant with the lectotype of $H$. onkodes (Table I). In addition, the measurements of conceptacle chambers of the lectotype of $H$. onkodes match perfectly that tetra/ bisporangial conceptacle of Mexican specimens (Table II) we found no clear differences between the lectotype and specimens from Mexico identified as $H$. onkodes. In fact, our observations confirm that in all Mexican specimens and lectotype specimen are very similar (Figs. 5a-f). Also, Penrose (1996) and (Adey et al. 1982) mentioned that trichocytes are commonly arranged singly, in small horizontal rows and in large pustulous arrangement. We found trichocytes to occur singly, in horizontal rows and large pustulous fields. Ours is the first record of Hydrolithon onkodes from the Atlantic coast of Mexico and the Mexican Caribbean.

Hydrolithon onkodes is essentially a tropical species and has been recorded from Australia, South Africa, Indian Ocean, Hawaiian Islands, New Guinea and the Pacific coast of Mexico. 

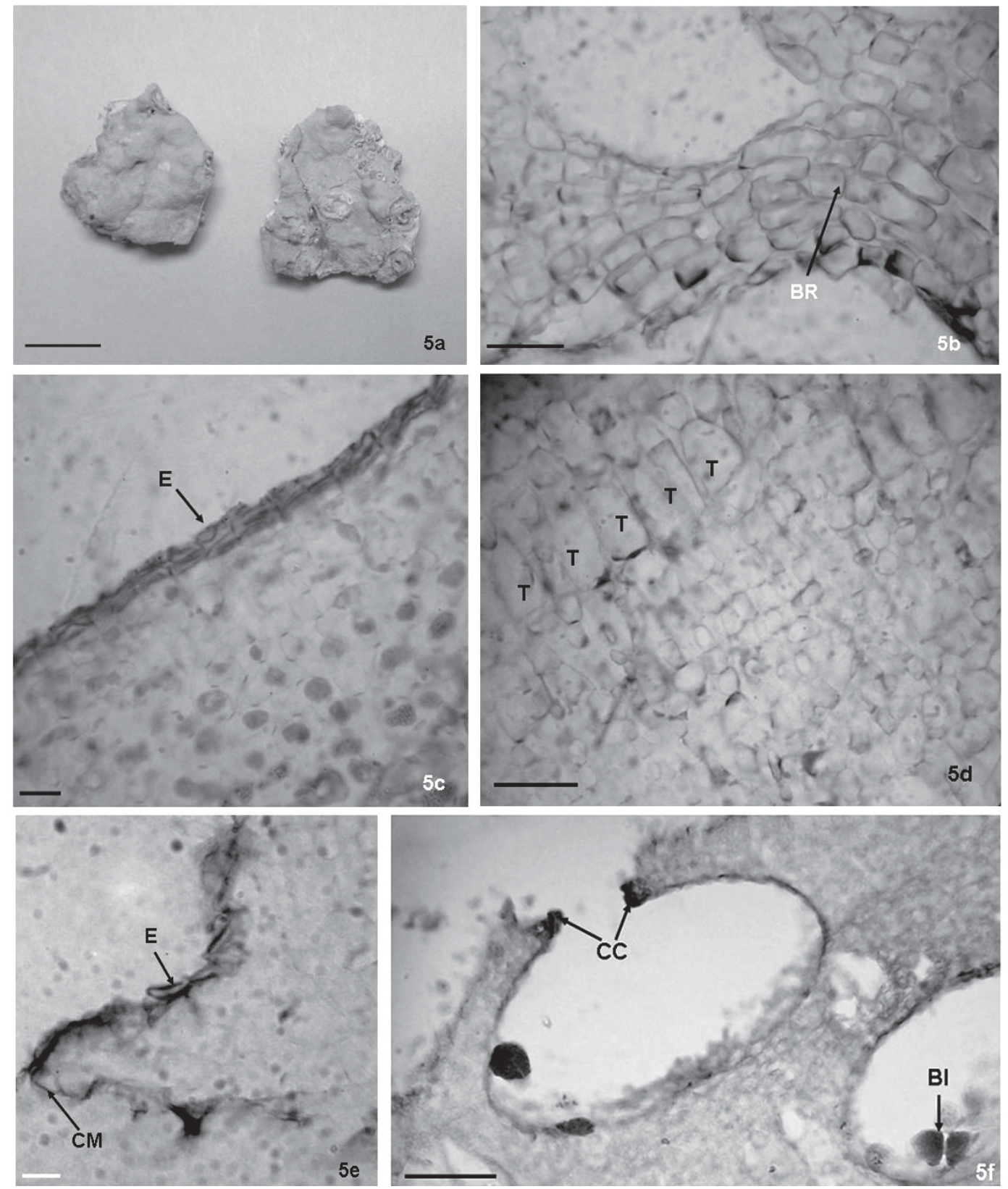

FIGURE 5. Lectotype (LT) of Hydrolithon onkodes. These fragments correspons with specimen on extreme right showed by Penrose et Woelkerling (1988: 81, figs. 4, 5). a. Habit of sporangial plant. Scale: $2 \mathrm{~cm}$. b. Section through a monomerous thallus showing a multistratose basal region(BR) with downward curving filaments. Scale: $25 \mu \mathrm{m}$. c. Section through cortical region of the thallus showing a four layers of epithallial cells (E) Scale $15 \mu \mathrm{m}$. d. Trichocytes in horizontal rows (T). Scale: 30 $\mu \mathrm{m}$. e. Close-up the meristhematic cell (CM) and the unistratose epithallium (E). Scale $25 \mu \mathrm{m}$. f. A bisporangial conceptacle with bisporangium (BI) and showing a pore canal lined by enlarged cells (CC). Scale: $75 \mu \mathrm{m}$.

FIGURA 5. Lectotipo de Hydrolithon onkodes. Estos fragmentos concuerdan con lo mostrado por Penrose et Woelkerling (1988: 81, figs. 4, 5). a. Hábito del talo esporangial. Escala: $2 \mathrm{~cm}$. b. Corte longitudinal del talo monómero que muestra una región basal multiestratosa (BR) con filamentos que siguen el contorno del sustrato. Escala: $25 \mu$ m. c. Sección mostrando cuatro capas de células epiteliales (E). Escala $15 \mu \mathrm{m}$. d. Tricocitos en hileras horizontales (T). Escala: $30 \mu \mathrm{m}$. e. Acercamiento de la célula meristemática $(\mathrm{CM})$ y células epiteliales (E). Escala $25 \mu \mathrm{m}$. f. Conceptáculo bisporangial con bisporangios (BI) y poro con células del canal (CC). Escala: $75 \mu \mathrm{m}$. 
The genus Hydrolithon in the Atlantic coast of México: Mendoza-GonzÁlez, C. ET AL.

4. Hydrolithon pachydermum (Foslie) J.C.Bailey, J.E.Gabel \& D.W.Freshwater. Phycologia 43(1): 8. 2004.

Basionym: Lithophyllum onkodes f. pachydermum Foslie, K. Norske Vidensk. Selsk. Skr. 2: 5. 1904. Synonyms: Lithophyllum pachydermum (Foslie) Adey et Lebednik, K. Norske Vidensk. Selsk. Skr. 1: 47. 1967; Porolithon pachydermum (Foslie) Foslie, K. Norske Vidensk. Selsk. Skr. 2: 57.1909.

Lectotype: TRH, A26-1553 Ǿrsted no. 548! (designated by Adey in Adey and Lebednik, 1967: 47).

Type locality: St. Croix (?), West Indies.

Habit And Vegetative Structure. Plants attached to the substratum ventrally by cell adhesion, without rhizoids, with small rounded protuberances (Fig. 6a), $400 \mu \mathrm{m}-2.7 \mathrm{~mm}$ thick, the crusts can be overlapping; thallus pseudoparenchymatous, cells of adjacent filaments connected laterally by fusions, secondary pit-connections not seen; thallus construction predominantly dimerous; basal region unistratose with rounded, square cells 15 $\mu \mathrm{m}$ diameter, to rectangular cells $6-15 \mu \mathrm{m}$ diameter and 15-24 $\mu \mathrm{m}$ high, or multistratose with square and rectangular cells 12-21 $\mu \mathrm{m}$ diameter and 6-12 $\mu \mathrm{m}$ tall, some of which have cell fusions; dorsal region composed of filaments that become oriented perpendicularly to the thallus surface, cells rounded, square, 6-15 $\mu \mathrm{m}$ diameter, or rectangular, 6-15 $\mu \mathrm{m}$ diameter, 15-21 $\mu \mathrm{m}$ high, or irregular with fusions and 3-15 $\mu \mathrm{m}$ diameter and 6-18 $\mu \mathrm{m}$ tall; each dorsal filament terminated by an oblong epithallial cell 6-12 $\mu \mathrm{m}$ diameter, 3-6 $\mu \mathrm{m}$ high, that form a unistratose layer (Fig. 6b); trichocytes single, in vertical and horizontal rows and large pustulous rows (Fig. 6c), 9-29 $\mu \mathrm{m}$ diameter and 15-54 $\mu \mathrm{m}$ tall; marginal growth by a irregular shaped cell 15 $33 \mu \mathrm{m}$ diameter and 12-24 $\mu \mathrm{m}$ tall (Fig. 6d).

Reproductive Structures: Tetra/bisporangial plants $480 \mu \mathrm{m}-2.7 \mathrm{~mm}$ thick, conceptacles buried in pseudoparenchymatous tissue, congested or widely scattered; tetra/bisporangial chambers orbicular or elliptical, small, 102-165/63-225 $\mu \mathrm{m}$ in diameter and 30-114/75-165 $\mu \mathrm{m}$ high, roof of conceptacle 3-12 cells thick and 24-30 $\mu \mathrm{m}$ tall, pore canals lined by cells oriented perpendicular to the thallus surface, triangular, longer $4.5 \mu \mathrm{m}$ diameter, $18 \mu \mathrm{m}$ tall or convex, 3-9 $\mu \mathrm{m}$ diameter, 15-24 $\mu \mathrm{m}$ tall, lacking a central columella, tetrasporangium 15-24 $\mu \mathrm{m}$ diameter and 45-48 $\mu \mathrm{m}$ tall (Fig. 6f). Bisporangium 51-84 $\mu \mathrm{m}$ diameter and $60-105 \mu \mathrm{m}$ tall (5e).

Specimens eXAmined: MEXICO, Veracruz, Punta Morro (1944'17'N, 96²4'01'W), 14-XI-1994, C. Mendoza \& L.E. Mateo s.n. (ENCB 17197), Quintana Roo, Cozumel Island, Chen Río, $\left(20^{\circ} 23^{\prime} 18^{\prime \prime} \mathrm{N}, 86^{\circ} 52^{\prime} 08^{\prime \prime} \mathrm{W}\right), 11-\mathrm{IX}-1985$, L.E. Mateo \& C. Mendoza s.n. (ENCB 17196), San Miguel Cozumel (20³0'28'N, 86'57'37'W), 26-II-1985, L.E. Mateo \& C. Mendoza s.n. (ENCB 17195).

HABitat: Epilithic on rocks, and encrusting dead coral skeletons, intertidal.

Remarks: Mexican specimens of $H$. pachydermum agree well with the lectotype of Lithophyllum onkodes f. pachydermum from Virgin Islands (TRH Ørsted no. 548). Table I and II, contains data, which showed this similitude. The measurements of epithelial, cortical, and medullar cells are concordant between both lectotype and Mexican specimens (Figs. 7a, b, c, d). The tetra/bisporangial chambers are similar in size and shape in both lectotype and H. pachydermum from Mexico (Figs. 7e, f and Table II). Nevertheless, $H$. onkodes and $H$. pachydermum from Mexico are very similar, the differences between them are: The number of epithallial's layers cells, the occurrence and arrangement of trichocytes and the sporangial pore canal cells shape. In the other hand, ours specimens agree in general characters with the description given by Taylor (1960) for Porolithon pachydermum (Foslie) Foslie.

H. pachydermum has been recorded in several localities from Caribbean as $P$. pachydermum (Littler \& Littler 2000). 

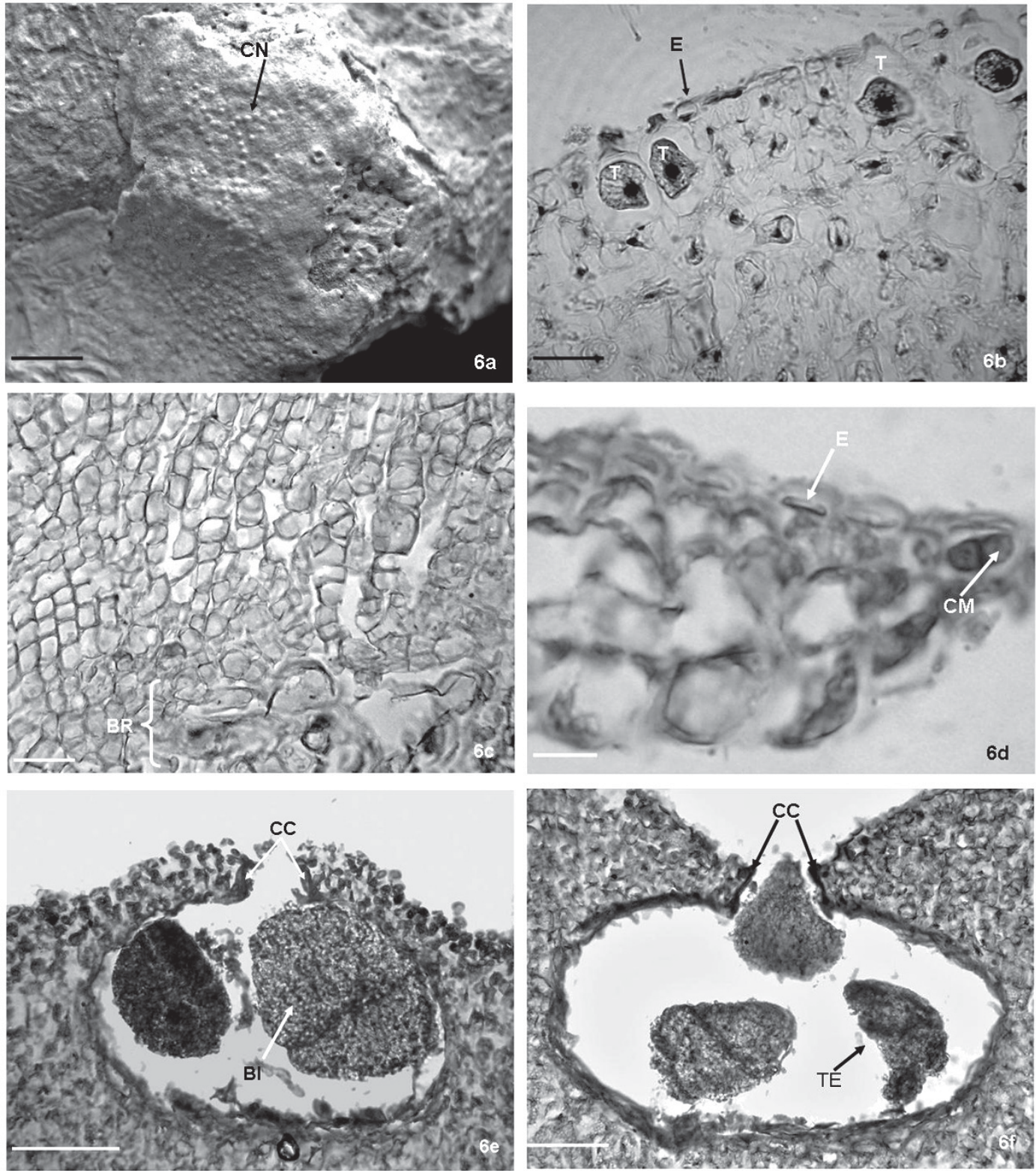

FIGURE 6. Hydrolithon pachydermum, Cozumel Island 26-II-1985 (ENCB 17 195). a. Surface of thallus showing conceptacles $(\mathrm{CN})$.Scale: $6 \mathrm{~mm}$. b. Section of thallus showing solitary trichocytes $(\mathrm{T})$ as well and in horizontal rows and epithallial cels (E). Scale: $29 \mu \mathrm{m}$. c. A monomerous thallus showing a thin multistratose basal region (BR) from which upwards derivatives are being formed. Scale: $22 \mu \mathrm{m}$. d. Close-up the meristhematic cell (CM), and the unistratose epithallium. Scale: $30 \mu \mathrm{m}$. e. Bisporangial conceptacle showing bisporangia (BI), and pore canal lined by enlarged cells (CC). Scale: $24 \mu \mathrm{m}$. f. Tetrasporangial conceptacle showing tetrasporangium (TE) and pore canal lined by enlarged cells (CC). Scale: $20 \mu \mathrm{m}$.

FiguRa 6. Hydrolithon pachydermum, Isla Cozumel, 26-II-1985 (ENCB 17 195). a. Superficie del talo mostrando los conceptáculos (CN).Escala: $6 \mathrm{~mm}$. b. Sección del talo mostrando tricocitos solitarios y en hilera horizontal, y las celulas epiteliales (E). Escala: $29 \mu \mathrm{m}$. c. Talo monómero mostrando una delgada región basal multiestratosa, (BR) de la cual emergen filamentos de células. Escala: $22 \mu \mathrm{m}$. d. Detalle de la célula meristemática (CM) y una capa de células epiteliales (E). Escala: $30 \mu \mathrm{m}$. e. Conceptáculo bisporangial con bisporangio (BI), poro delineado por células alargadas (CC). Escala: $24 \mu \mathrm{m}$. f. Conceptáculo tetrasporangial con tetrasporangio (TE) y poro delineado por células alargadas (CC). Escala: $20 \mu \mathrm{m}$. 
The genus Hydrolithon in the Atlantic coast of México: Mendoza-GonzÁlez, C. ET AL.
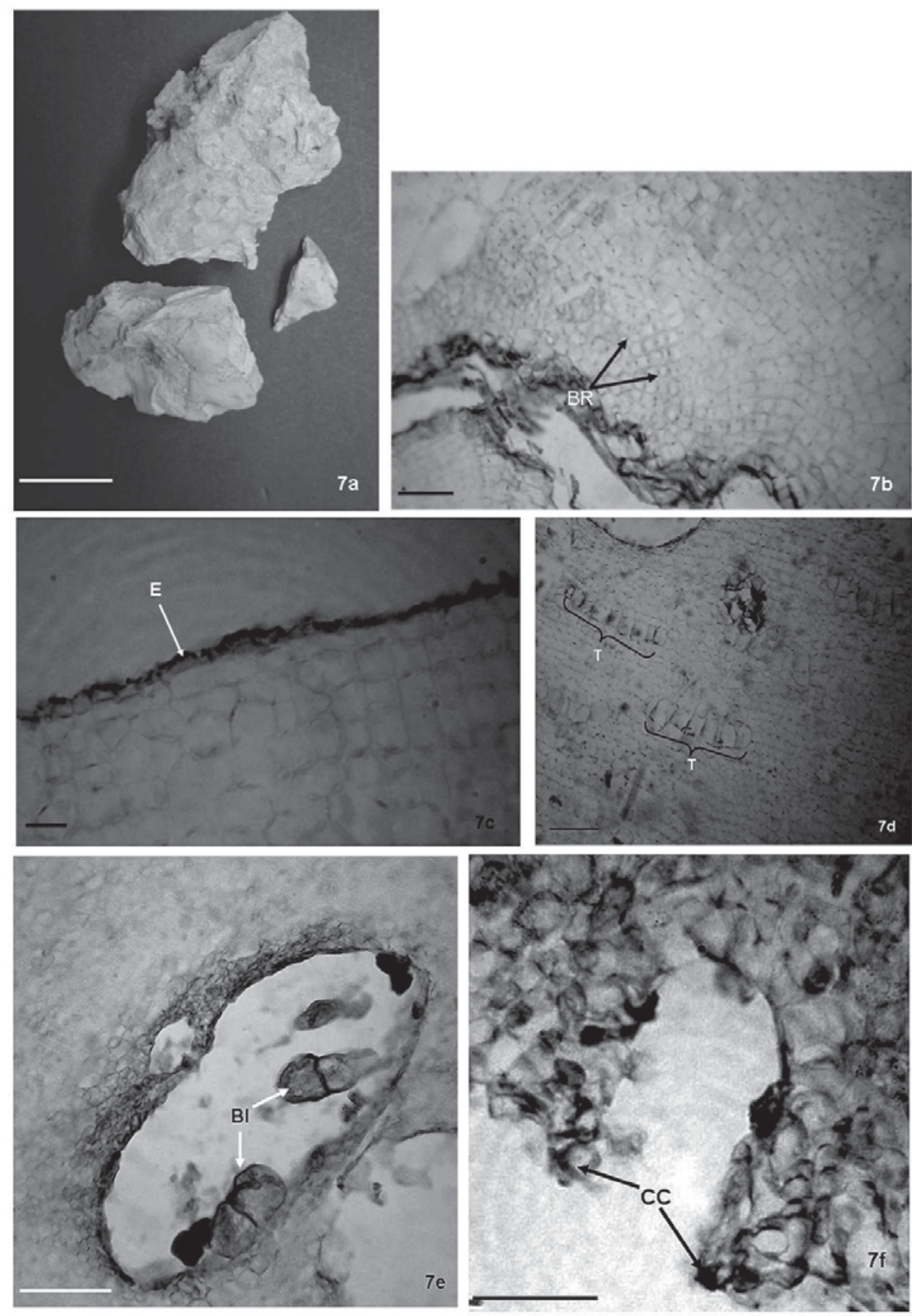

FIGURE 7. Lectotype of Hydrolithon pachydermum. a. Habit of bisporangial plant. Scale: $3 \mathrm{~cm}$. b. Section through a monomerous thallus showing a multistratose basal region (BR) with downward curving filaments. Scale: $40 \mu \mathrm{m}$. c. Section through cortical region of the thallus showing a unistratose epithallium (E). Scale: $10 \mu \mathrm{m}$. d. Trichocytes arranges in horizontal rows (T). Scale: $45 \mu \mathrm{m}$. e. A buried conceptacle showed bisporangium (BI). Scale: $45 \mu \mathrm{m}$. f. Close-up of conceptacle showing a pore canal lined by enlarged cells (CC). Scale: $25 \mu \mathrm{m}$.

FiguRa 7. Lectotipo of Hydrolithon pachydermum. a. Habito del talo costroso. Escala: $3 \mathrm{~cm}$. b. Talo monómero mostrando una región basal multiestratosa, (BR) de la cual emergen filamentos de células. Escala: $40 \mu \mathrm{m}$. c. Sección de la región cortical donde se observa un epitalo unistratificado (E). Escala: $10 \mu \mathrm{m}$. d. Sección del talo mostrando hileras horizontales de tricocitos (T). Escala: $45 \mu \mathrm{m}$. e. Conceptáculo bisporangial con bisporangios (BI). Escala: $45 \mu \mathrm{m}$. f. Acercamiento del canal del conceptáculo, mostrando el poro delineado por células alargadas (CC). Escala: $25 \mu \mathrm{m}$. 
Gayana Bot. 66(2), 2009

TABLE I. Morphoanatomical characteristics of Hydrolithon onkodes and H. pachydermum (lectotypes and Mexican specimens).

TABLA I. Caracteres morfológicos de Hydrolithon onkodes y H. pachydermum (lectotipos y especímenes mexicanos).

\begin{tabular}{|c|c|c|c|c|}
\hline Character & $\begin{array}{l}\text { Hydrolithon } \\
\text { onkodes (from } \\
\text { Mexico) }\end{array}$ & $\begin{array}{l}\text { H. onkodes } \\
\text { (lectotype) }\end{array}$ & $\begin{array}{l}\text { H. pachydermum } \\
\text { (from Mexico) }\end{array}$ & $\begin{array}{l}\text { H. pachydermum } \\
\text { (lectotype) }\end{array}$ \\
\hline Habit & $\begin{array}{l}\text { Encrusting or with } \\
\text { small protuberances }\end{array}$ & Encrusting & $\begin{array}{c}\text { With small } \\
\text { protuberances }\end{array}$ & Encrusting \\
\hline Thallus construction & $\begin{array}{c}\text { Mostly } \\
\text { monomerous }\end{array}$ & Monomerous & $\begin{array}{c}\text { Mostly } \\
\text { monomerous }\end{array}$ & Monomerous \\
\hline Medulla & No coaxial & No coaxial & No coaxial & No coaxial \\
\hline Epithallium & 1-4 layers & 3-4 layers & Unistratose & Unistratose \\
\hline Trichocytes & $\begin{array}{l}\text { Singly, in horizontal } \\
\text { rows or in field } \\
\text { pustules }\end{array}$ & $\begin{array}{l}\text { Singly, in horizontal } \\
\text { rows or in field } \\
\text { pustules }\end{array}$ & $\begin{array}{l}\text { Singly, or in } \\
\text { horizontal rows, } \\
\text { rarely in field } \\
\text { pustules }\end{array}$ & $\begin{array}{c}\text { Singly, or in } \\
\text { horizontal rows }\end{array}$ \\
\hline Cell Fusions & Present & Present & Present & Present \\
\hline Epithallial cells & $\begin{array}{c}3-9 \mu \mathrm{m} \text { tall } \\
5-8 \mu \mathrm{m} \text { diam. }\end{array}$ & $\begin{array}{c}3-4 \mu \mathrm{m} \text { tall } \\
7-11 \mu \mathrm{m} \text { diam. }\end{array}$ & $\begin{array}{c}3-6 \mu \mathrm{m} \text { tall } \\
6-12 \mu \mathrm{m} \text { diam. }\end{array}$ & $\begin{array}{c}4-6 \mu \mathrm{m} \text { tall } \\
9-13 \mu \mathrm{m} \text { diam. }\end{array}$ \\
\hline Cortical cells & $\begin{array}{c}\text { 6-9 } \mu \mathrm{m} \text { tall } \\
8-18 \mu \mathrm{m} \text { diam. }\end{array}$ & $\begin{array}{c}9-15 \mu \mathrm{m} \text { tall } \\
6-12 \mu \mathrm{m} \text { diam. }\end{array}$ & $\begin{array}{l}15-21 \mu \mathrm{m} \text { tall } \\
6-15 \mu \mathrm{m} \text { diam. }\end{array}$ & $\begin{array}{l}12-15 \mu \mathrm{m} \text { tall } \\
9-12 \mu \mathrm{m} \text { diam. }\end{array}$ \\
\hline Medullary cells & $\begin{array}{c}4-13 \mu \mathrm{m} \text { tall } \\
9-30 \mu \mathrm{m} \text { diam. }\end{array}$ & $\begin{array}{l}14-22 \mu \mathrm{m} \text { tall } \\
7-9 \mu \mathrm{m} \text { diam. }\end{array}$ & $\begin{array}{c}6-12 \mu \mathrm{m} \text { tall } \\
12-21 \mu \mathrm{m} \text { diam. }\end{array}$ & $\begin{array}{l}18-20 \mu \mathrm{m} \text { tall } \\
7-11 \mu \mathrm{m} \text { diam. }\end{array}$ \\
\hline Trichocytes size & $\begin{array}{l}18-33 \mu \mathrm{m} \text { high } \\
12-24 \mu \mathrm{m} \text { diam. }\end{array}$ & $\begin{array}{l}18-26 \mu \mathrm{m} \text { high } \\
16-22 \mu \mathrm{m} \text { diam. }\end{array}$ & $\begin{array}{l}27-54 \mu \mathrm{m} \text { high } \\
18-26 \mu \mathrm{m} \text { diam. }\end{array}$ & $\begin{array}{l}32-41 \mu \mathrm{m} \text { high } \\
24-26 \mu \mathrm{m} \text { diam. }\end{array}$ \\
\hline Thallus thickness & $0.2-4.0 \mathrm{~mm}$ thick & $12-25 \mathrm{~mm}$ thick & $0.4-2.7 \mathrm{~mm}$ thick & $1.9-2.0 \mathrm{~mm}$ thick \\
\hline
\end{tabular}

TABLE II. Reproductive characteristics of Hydrolithon onkodes and H. pachydermum (lectotypes and Mexican specimens).

TABLA II. Caracteres reproductivos de Hydrolithon onkodes y H. pachydermum (lectotipos y especímenes mexicanos).

\begin{tabular}{|c|c|c|c|c|}
\hline Character & $\begin{array}{c}\text { Hydrolithon } \\
\text { onkodes (from } \\
\text { Mexico) } \\
\end{array}$ & $\begin{array}{l}\text { H. onkodes } \\
\text { (lectotype) }\end{array}$ & $\begin{array}{l}\text { H. pachydermum } \\
\text { (from Mexico) }\end{array}$ & $\begin{array}{l}\text { H. pachydermum } \\
\text { (lectotype) }\end{array}$ \\
\hline $\begin{array}{l}\text { Chamber size of } \\
\text { tetra/bisporangial } \\
\text { conceptacle }\end{array}$ & $\begin{array}{c}\text { 36-165/ 36-180 } \mu \mathrm{m} \\
\text { high, 186-231/141- } \\
255 \mu \mathrm{m} \text { diameter }\end{array}$ & $\begin{array}{l}111 \mu \mathrm{m} \text { high and } \\
233 \mu \mathrm{m} \text { diameter }\end{array}$ & $\begin{array}{c}102-165 / 63-225 \mu \mathrm{m} \\
\text { diameter 30-114/75- } \\
165 \mu \mathrm{m} \text { high }\end{array}$ & $\begin{array}{c}126 \mu \mathrm{m} \text { high } \\
222 \mu \mathrm{m} \text { diameter }\end{array}$ \\
\hline Chambers shape & elliptic or rounded & elliptic & $\begin{array}{l}\text { orbicular, elliptic or } \\
\text { rounded }\end{array}$ & Orbicular \\
\hline $\begin{array}{l}\text { Tetra/bisporangia } \\
\text { size }\end{array}$ & $\begin{array}{c}16-51 / 21-75 \mu \mathrm{m} \\
\text { diameter } 36-72 / 41- \\
95 \mu \mathrm{m} \text { high }\end{array}$ & $\begin{array}{l}22 \mu \mathrm{m} \text { diameter } \\
32 \mu \mathrm{m} \text { high } \\
\text { Apparently } \\
\text { bisporangium }\end{array}$ & $\begin{array}{c}15-24 / 51-84 \mu \mathrm{m} \\
\text { diameter, } 45-48 / 60- \\
105 \mu \mathrm{m} \text { high }\end{array}$ & $\begin{array}{c}15 \mu \mathrm{m} \text { diameter and } \\
45 \text { high }\end{array}$ \\
\hline Columella & Present & Present & Absent & Absent \\
\hline Roof layers & $4-8$ & $6-9$ & $3-4$ & 4 \\
\hline
\end{tabular}


The genus Hydrolithon in the Atlantic coast of México: Mendoza-GonzÁlez, C. ET AL.

5. Hydrolithon reinboldii (Weber-van Bosse et Foslie) Foslie, K. Norske Vidensk. Selsk. Biol. Skr. 2: 55.1909.

Basionym: Lithophyllum reinboldii Weber-van Bosse et Foslie, K. Norske Vidensk. Selsk. Biol. Skr. 2: 5. 1901.

Synonyms: Goniolithon reinboldii (Weber-van Bosse et Foslie) Weber van Bosse et Foslie, K. Norske Vidensk. Selsk. Biol. Skr. 2: 49. 1904; Porolithon reinboldii (Weber-van Bosse et Foslie) Lemoine, Ann. Inst. Oceanogr. Monaco 2(2): 166. 1911; Spongites reinboldii (Weber-van Bosse et Foslie) D.Penrose et Woelkerling, Phycologia 26: 173. 1988.

Type locality: Moearas Reef on the east coast of Borneo (East Kalimantan), Indonesia.

Habit And vegetative Structure: Attached to the substratum ventrally by cell adhesion, without rhizoids, $130 \mu \mathrm{m}-4 \mathrm{~mm}$ thick, also occurring as free-living rhodoliths with rounded protuberances (Fig. 8a), 4 to $5 \mathrm{~cm}$ thick; thallus pseudoparenchymatous; cells of adjacent filaments connected laterally by fusions, secondary pitconnections not observed; thallus construction dimerous, basal region unistratose, with square cells $12-15 \mu \mathrm{m}$ diameter, others vertically elongate, 12-45 $\mu \mathrm{m}$ tall and 9-24 $\mu \mathrm{m}$ diameter with several fusions (Fig. 8b); epithallial cells in unistratose layer with oblong cells $1.5-9 \mu \mathrm{m}$ tall and 4.5$15 \mu \mathrm{m}$ diameter; cortical region composed of filaments that become oriented perpendicularly to the thallus surface. Cells of erect filaments are strongly horizontally arranged (Fig. 8c) due to extensive connections by broad cell fusions; cells rounded, square 6-15 $\mu \mathrm{m}$ diameter, irregular cell fusion 6-25 $\mu \mathrm{m}$ diameter and 9-30 $\mu \mathrm{m}$ tall; trichocytes single, or in vertical rows, 6-27 $\mu \mathrm{m}$ diameter and 15-45 $\mu \mathrm{m}$ tall; marginal growth by irregularly shaped initial cells $12-33 \mu \mathrm{m}$ in diameter and 12-24 $\mu \mathrm{m}$ tall (Fig. 8d).

REPRODUCTIVE STRUCTURES. Tetra/bisporangial plants $140 \mu \mathrm{m}-4 \mathrm{~mm}$ thick, tetra/bisporangial conceptacles domoid and apiculate; tetra/bisporangial chambers rounded, 88/195 $\mu \mathrm{m}$ diameter, or orbicular, $95 \mu \mathrm{m}$ diameter and 100/129 $\mu \mathrm{m}$ high, or elliptical, 165$180 / 250 \mu \mathrm{m}$ diameter and 105/205 $\mu \mathrm{m}$ high; roof of conceptacle 4 layers cells thick, 25-30 $\mu \mathrm{m}$ tall; and lacking central columella; pore canals lined by cells oriented perpendicular to the thallus surface, reniform to concave, $2.5-9 \mu \mathrm{m}$ diameter and $37 \mu \mathrm{m}$ tall, or triangular-longer 2.5-9 $\mu \mathrm{m}$ diameter and 24-37 $\mu \mathrm{m}$ tall; the sterile filaments given raise to the roof still persistent in the conceptacle chamber (Fig. 8e); tetrasporangium 15-69 $\mu \mathrm{m}$ diameter and 50-84 $\mu \mathrm{m}$ high, bisporangium 33-125 $\mu \mathrm{m}$ diameter and $62-102 \mu \mathrm{m}$ tall (Fig. 8f).

Specimens eXAmined: MEXICO, Veracruz, Arrecife La Blanquilla $\left(19^{\circ} 13^{\prime} 24^{\prime \prime} \mathrm{N}, 96^{\circ} 05^{\prime} 54^{\prime \prime} \mathrm{W}\right), 3-\mathrm{V}-$ 1964, L. Huerta s.n. (ENCB 17159), Quintana Roo, Cozumel Island, (20³0'32'N, 86 $\left.{ }^{\circ} 57^{\prime} 07^{\prime} \mathrm{W}\right)$, 10-IX-1985，20-V-1993; 14-IX-1993; 19-III1994, C. Mendoza, L.E. Mateo, L. Huerta \& C. Galicia s.n. (ENCB 17162, 17165, 17167, 17168), San Francisco Reef, 17-V-1993, L.E. Mateo, C. Mendoza \& L. Huerta s.n. (ENCB 17170), Playa San Juan, (20³3'02'NN, 86 55'49'W), 17-III1994, L.E. Mateo, C. Mendoza \& R. Robles s.n. (ENCB 17163), 2-VI-1995, Tunich Reef, R. Robles \& E. Caister s.n. (ENCB 17171), Mujeres Island, Garrafón Reef $\left(21^{\circ} 12^{\prime} 12.9^{\prime \prime} \mathrm{N}, 8^{\circ} 43^{\prime} 16.5 \mathrm{~W}\right), 20$ V-1998, L.E. Mateo \& C. Mendoza s.n. (ENCB 17161), Punta Norte, 13-IX-1985, C. Mendoza \& L.E. Mateo s.n. (ENCB 17160), Banco Chinchorro, Cayo Lobos $\left(18^{\circ} 23^{\prime} 11^{\prime \prime N}, 87^{\circ} 22^{\prime} 53^{\prime \prime} \mathrm{W}\right), 19-\mathrm{VI}-$ 1984, L. Huerta \& L.E. Mateo s.n. (ENCB 17166), Akumal $\left(20^{\circ} 23^{\prime} 9.8^{\prime \prime} \mathrm{N}, 87^{\circ} 19^{\prime} 21.6 ” \mathrm{~W}\right), 16-\mathrm{IX}-$ 1993, C. Mendoza, L.E. Mateo, R. Robles \& R.B. Searles s.n. (ENCB 17164).

Habitat: Epilithic on rocks, and encrusting dead coral skeletons or as free-living rhodoliths, intertidal and subtidal.

REMARKS: Our observations of this species are in general agreement with the descriptions of Lemoine (1917), Mason (1954), Dawson (1960), Adey \& Lebednik (1967), and Penrose \& Woelkerling (1992), except for the relatively small size of the sporangial conceptacles in our specimens. Desikachary \& Ganesan (1967), however, have described tetrasporangial conceptacles similar in size to those we observed. We did not observed gametangial plants, but Krishnamurthy \& Jayagopal (1987) described a procarpic conceptacle $150 \mu \mathrm{m}$ in diameter and 40 $\mu \mathrm{m}$ high, spermatangial conceptacles $40-70 \mu \mathrm{m}$ in diameter and 25-50 $\mu \mathrm{m}$ high.

No previously published descriptions of this taxon included information of the size and shape of sporangial conceptacle pore canal cells. Bisporangial plants were more common than tetrasporangial plants. This species occurs 
in Veracruz and Quintana Roo and is the first record from the Atlantic coast of Mexico. In the other hand, $H$. reinboldii has been recorded from Revillagigedo Island at the Pacific coast of Mexico by Dawson (1960) and Adey et al. (1982).
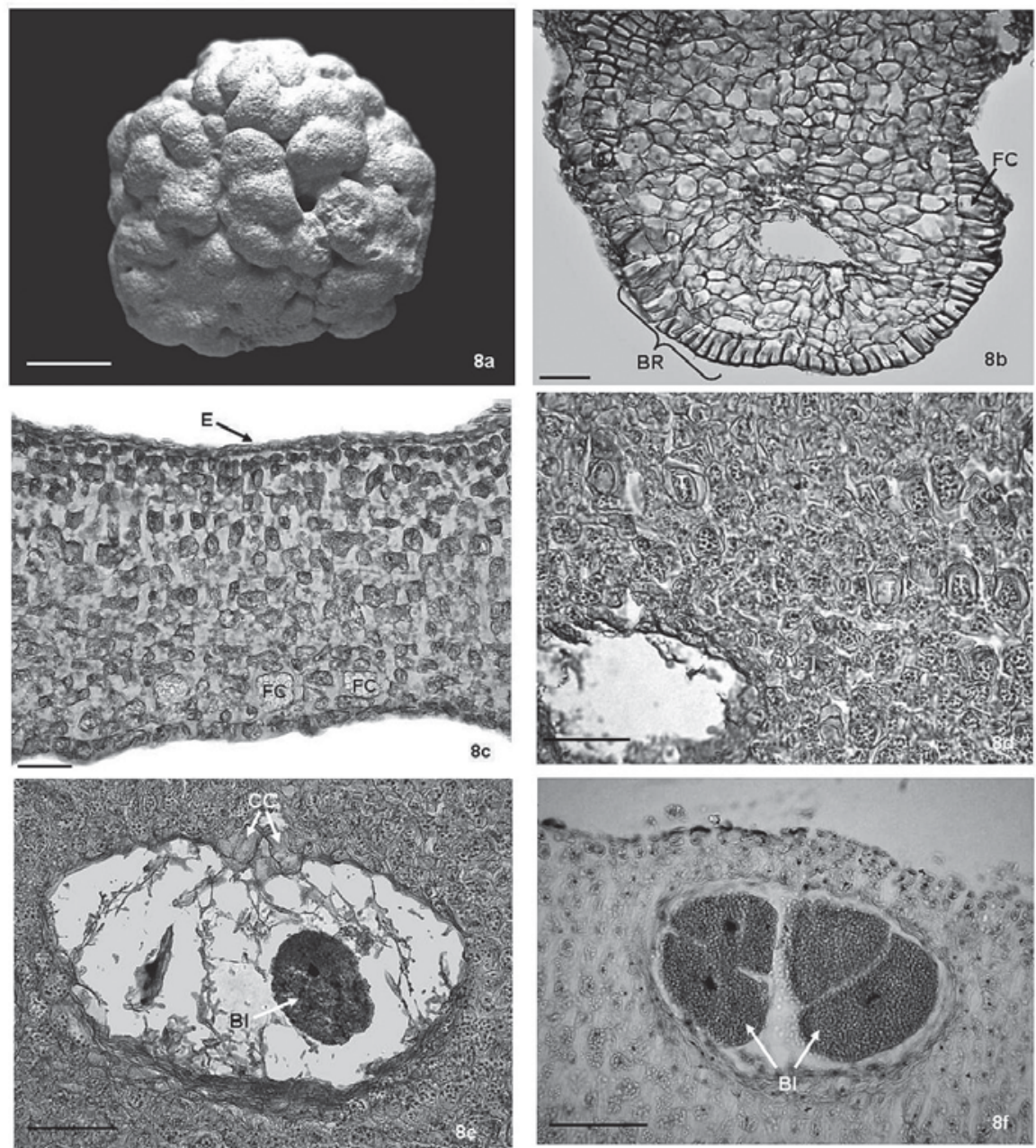

FIGURE 8. Hydrolithon reinboldii, Cozumel Island, 14-IX-1993 (ENCB 17 162). a. A free-living Rhodolith with several rounded and fused protuberances. Scale: $8 \mathrm{~mm}$. b. Section of the thallus showing the dimerous construction with a unistratose basal region (BR) bearing extensive cell fusions (FC). Scale: $37 \mu \mathrm{m}$. c. Longitudinal view of the dimerous thallus showing a single epithallial layer $(\mathrm{E})$. Note too the strong horizontal arrangement of the erect filaments resulting from extensive cell fusions between adjacent erect filaments. Scale: $22 \mu \mathrm{m}$. d. Section of thallus showing numerous solitary trichocytes $(\mathrm{T})$. Scale: $40 \mu \mathrm{m}$. e. Section through a bisporangial conceptacle showing a pore canal lined by enlarged cells (CC) and bisporangium. Scale: $44 \mu \mathrm{m}$. f. Bisporangial conceptacle showing two mature bisporangium (BI). Scale: $69 \mu \mathrm{m}$.

FIGURA 8. Hydrolithon reinboldii, Isla Cozumel, 14-IX-1993 (ENCB 17 162). a. Un rodolito de hábito libre, con numerosas protuberancias redondeadas y fusionadas. Escala: $8 \mathrm{~mm}$. b. Sección longitudinal que muestra una construcción dímera con una región basal uniestratosa (BR) y con numerosas fusiones celulares (FC). Escala: $37 \mu \mathrm{m}$. c. Sección longitudinal del talo dímero mostrando una capa de las células epiteliales (E). Observe el marcado arreglo horizontal de los filamentos erguidos y que muestran numerosas fusiones celulares entre filamentos adyacentes (FC). Escala: 22 $\mu \mathrm{m}$. d. Sección del talo que muestra numerosos tricocitos solitarios (T). Escala: $40 \mu \mathrm{m}$. e. Conceptáculo bisporangial con poro delineado por células alargadas (CC) y bisporangios (BI). Escala: $69 \mu \mathrm{m}$. f. Sección del talo bisporangial con dos bisporangios (BI). Escala: $44 \mu \mathrm{m}$. 
The genus Hydrolithon in the Atlantic coast of México: Mendoza-GonzÁlez, C. ET AL.

\section{DISCUSSION AND CONCLUSION}

The delimitation of the genus Hydrolithon was circumscribed by Penrose \& Woelkerling (1992) who indicated the main characters distinguishing Hydrolithon from other mastophoroid coralline algae and are: pore canals of sporangial conceptacles lined by a ring of conspicuous elongate cells that arise from filaments interspersed among sporangial initials.

The five species of Hydrolithon discussed here belong to Hydrolithon on the basis of their mastophoroid characters in combination with the above sporangial pore structure; have confirmed the presence of this species in the waters of eastern Mexico. In the other hand, the clearest differences between into the species are: the habit, if is crustose, with protuberances or freeliving rhodoliths; the construction of the thallus is dimerous or monomerous; the occurrence of trichocytes singly, in horizontal and vertical rows or in field pustules, although trichocytes may be present singly or in field pustules in the same species (Table III). The distinguishing reproductive features of our Hydrolithon's taxa are as follows: gametangial plants monoecious or dioecious; shape and size of tetra/bisporangial chambers as well as the size and shape of the pore canal cells (Table IV).

TABLE III. Morphological characters of Hydrolithon species from the Atlantic Coast of Mexico and Mexican Caribbean.

TABLA III. Caracteres morfológicos de las especies de Hydrolithon presentes en la costa del Atlántico y Caribe mexicano.

\begin{tabular}{|c|c|c|c|c|c|}
\hline Character & H. boergesenii & H. farinosum & H. onkodes & $\begin{array}{c}H . \\
\text { pachydermum }\end{array}$ & H. reinboldii \\
\hline Habit & $\begin{array}{l}\text { Crustose } \\
\text { with warty } \\
\text { protuberances }\end{array}$ & $\begin{array}{c}\text { Crustose } \\
\text { smooth lacking } \\
\text { protuberances }\end{array}$ & $\begin{array}{l}\text { Crustose, } \\
\text { warty or } \\
\text { lumpy }\end{array}$ & $\begin{array}{c}\text { Crustose } \\
\text { with small } \\
\text { protuberances }\end{array}$ & $\begin{array}{l}\text { Unattached } \\
\text { (rhodoliths) or } \\
\text { crustose with } \\
\text { numerous round } \\
\text { protuberances }\end{array}$ \\
\hline $\begin{array}{l}\text { Sporangial } \\
\text { Thallus } \\
\text { Thickness }\end{array}$ & $0.4-2 \mathrm{~mm}$ & $20-90 \mu \mathrm{m}$ & $0.2-4 \mathrm{~mm}$ & $0.4-2.7 \mathrm{~mm}$ & $\begin{array}{l}\text { Crustose } 0.1-4 \mathrm{~mm} \\
\text { rhodoliths } 4-5 \mathrm{~cm}\end{array}$ \\
\hline $\begin{array}{l}\text { Thallus } \\
\text { Construction }\end{array}$ & Dimerous & Dimerous & $\begin{array}{c}\text { Mostly } \\
\text { Monomerous }\end{array}$ & $\begin{array}{c}\text { Mostly } \\
\text { Monomerous }\end{array}$ & Dimerous \\
\hline Basal region & Unistratose & Unistratose & Multistratose & Multistratose & $\begin{array}{l}\text { Unistratose rarely } \\
\text { multistratose }\end{array}$ \\
\hline $\begin{array}{l}\text { Arranged cell of } \\
\text { erect filaments }\end{array}$ & $\begin{array}{l}\text { No horizontally } \\
\text { arranged }\end{array}$ & $\begin{array}{l}\text { No horizontally } \\
\text { arranged }\end{array}$ & $\begin{array}{c}\text { No } \\
\text { horizontally } \\
\text { arranged }\end{array}$ & $\begin{array}{l}\text { No horizontally } \\
\text { arranged }\end{array}$ & $\begin{array}{l}\text { Strongly } \\
\text { horizontally } \\
\text { arranged }\end{array}$ \\
\hline Epithallium & $\begin{array}{l}\text { Unistratose or } \\
\text { bistratose }\end{array}$ & Unistratose & 3-4 layers & Unistratose & Unistratose \\
\hline Trichocytes & $\begin{array}{l}\text { Solitary or in } \\
\text { horizontal and } \\
\text { vertical rows. }\end{array}$ & $\begin{array}{l}\text { Solitary and in } \\
\text { horizontal rows }\end{array}$ & $\begin{array}{c}\text { Solitary, } \\
\text { horizontal } \\
\text { rows and field } \\
\text { pustules }\end{array}$ & $\begin{array}{l}\text { Solitary, } \\
\text { horizontal and } \\
\text { vertical rows, } \\
\text { rarely field } \\
\text { pustules }\end{array}$ & $\begin{array}{l}\text { Solitary, in short } \\
\text { horizontal and } \\
\text { vertical rows }\end{array}$ \\
\hline
\end{tabular}


As we showed at Fig. 1, Hydrolithon farinosum is one of the most common species that occurs along the Atlantic and Caribbean coasts of Mexico. In contrast, $H$. boergesenii appears restricted to Cozumel Island, Quintana Roo and Yucatan. The present study should not be regarded as an exhaustive treatment of the diversity of Hydrolithon in eastern coast Mexico, but rather it is baseline study. The area surveyed encompasses $2768 \mathrm{~km}$ of coast along which less 70 sites were sampled, these sites represented less than $10 \%$ of the total coastline; for this reason is necessary to do further detailed studies in the rocky shores and reefs poorly know in the Atlantic and Caribbean coast of Mexico.

Finally, $H$. onkodes appears to be closely related to $H$. pachydermum and further ecological and molecular studies are needed to evaluate the Mexican populations of both taxa.

TABLE IV. Reproductive characters of Hydrolithon species from the Atlantic Coast of Mexico and Mexican Caribbean.

TABLA IV. Caracteres reproductivos de las especies de Hydrolithon presentes en la costa del Atlántico y Caribe mexicano.

\begin{tabular}{|c|c|c|c|c|c|}
\hline Character & H. boergesenii & H. farinosum & H. onkodes & $\begin{array}{c}H . \\
\text { pachydermum }\end{array}$ & H. reinboldii \\
\hline $\begin{array}{l}\text { Chamber } \\
\text { shape of tetra/ } \\
\text { bisporangial } \\
\text { conceptacle }\end{array}$ & elliptic or ovoid & elliptic & $\begin{array}{l}\text { elliptic or } \\
\text { rounded }\end{array}$ & $\begin{array}{l}\text { orbicular, } \\
\text { elliptic or } \\
\text { rounded }\end{array}$ & $\begin{array}{l}\text { orbicular, } \\
\text { elliptic or } \\
\text { rounded }\end{array}$ \\
\hline $\begin{array}{c}\text { Chamber } \\
\text { size of tetra/ } \\
\text { bisporangial } \\
\text { conceptacle }\end{array}$ & $\begin{array}{c}174-216 / 81-165 \\
\mu \mathrm{m} \text { in diameter } \\
\text { and } 81-96 \mu \mathrm{m} \\
\text { high }\end{array}$ & $\begin{array}{c}100-300 \mu \mathrm{m} \\
\text { diameter and } \\
31-100 \mu \mathrm{m} \text { high }\end{array}$ & $\begin{array}{c}36-165 / 36-180 \\
\mu \mathrm{m} \text { high, } 186- \\
231 / 141-255 \mu \mathrm{m} \\
\text { diameter }\end{array}$ & $\begin{array}{c}102-165 / 63-225 \\
\mu \mathrm{m} \text { diameter } \\
30-114 / 75-165 \\
\mu \mathrm{m} \text { high }\end{array}$ & $\begin{array}{c}165-180 / 250 \\
\mu \mathrm{m} \text { diameter } \\
\text { and } 100 / 205 \mu \mathrm{m} \\
\text { high }\end{array}$ \\
\hline $\begin{array}{c}\text { Tetra/ } \\
\text { bisporangia size }\end{array}$ & $\begin{array}{c}25-42 / 45-50 \mu \mathrm{m} \\
\text { in diameter and } \\
63 / 77-90 \mu \mathrm{m} \\
\text { high. }\end{array}$ & $\begin{array}{c}20-57 \mu \mathrm{m} \\
\text { diameter and } \\
31-63 \mu \mathrm{m} \text { high }\end{array}$ & $\begin{array}{c}\text { 16-51/21-75 } \\
\mu \mathrm{m} \text { diameter } \\
36-72 / 41-95 \mu \mathrm{m} \\
\text { high }\end{array}$ & $\begin{array}{c}\text { 15-24/51-84 } \mu \mathrm{m} \\
\text { diameter, } 45- \\
\text { 48/60-105 } \mu \mathrm{m} \\
\text { high }\end{array}$ & $\begin{array}{l}15-69 / 33-125 \\
\mu \mathrm{m} \text { diameter } \\
\text { and 50-84/62- } \\
102 \mu \mathrm{m} \text { high, }\end{array}$ \\
\hline Columella & Absent & Present & Present & Absent & Absent \\
\hline Roofs layers & $3-6$ & $2-3$ & $4-8$ & $3-4$ & 4 \\
\hline $\begin{array}{c}\text { Gametangial } \\
\text { thallus }\end{array}$ & not seen & dioecious & monoecious & not seen & not seen \\
\hline $\begin{array}{l}\text { Shape of canal's } \\
\text { cells }\end{array}$ & Concave & $\begin{array}{l}\text { Triangular- } \\
\text { Convex }\end{array}$ & Triangular & Elongated & $\begin{array}{l}\text { Reniform- } \\
\text { Triangular }\end{array}$ \\
\hline
\end{tabular}


Cultivo de diatomeas y dinoflagelados en sedimentos marinos: SÁNCHEZ, G. ET AL.

\section{ACKNOWLEDGMENTS}

This paper is a partial result of the first author's research for the Doctorado en Ciencias Biológicas program at Universidad Autónoma Metropolitana. Thanks to the Universidad Autónoma Metropolitana and the Instituto Politécnico Nacional for the support granted to this study and the Comisión de Operación y Fomento de Actividades Académicas IPN for support to the first author.

\section{BIBLIOGRAPHY}

Adey, W. H. \& P. A. LebedniK. 1967. Catalog of the Foslie Herbarium. Kjelder Norske Videnskabers Selskab skrifter, Trondheim, Norway. 92 pp.

AdEy, W.H.\&P.J.AdEY. 1973. Studies on the biosystematics and ecology of the epilithic crustose Corallinaceae of the British Isles. British Phycological Journal 8: 343-407.

Adey, W.H., R.A. Towsend \& W.T. Boykins. 1982. The crustose coralline algae (Rhodophyta, Corallinaceae) of the Hawaiian Islands. Smithsonian Contributions to the Marine Science 15(1-4): 1-74.

Bailey, J.C., J.E. Gabel \& D.W. Freshwater. 2004. Nuclear 18S rRNA gene sequence analyses indicate that the Mastophoroideae (Corallinaceae, Rhodophyta), is a polyphyletic taxon. Phycologia 43(1): 3-12.

Bailey J.C., Gabel J.E. \& Freshwater D.W. 2005. Nuclear 18S rRNA gene sequence analysis indicate that the Mastophoroideae (Corallinaceae, Rhodophyta) is a polyphyletic taxon. Addendum. Phycologia 44: 3.

Bressan, G., D. Miniati-Radin \& L. Smundin. 1977. Recherche sul genre Fosliella cruciata sp. nov. Nuovo Giornale Botanico Italiano 111: 27-44.

Chamberlain, Y.M. 1983. Studies in Corallinaceae with special reference to Fosliella and Pneophyllum in the British Isles. Bulletin of the British Museum (Natural History). Botany 11: 291-463.

Chamberlain, Y.M. 1994. Masthophoroideae Setchell. In: L.M. Irvine \& Y. Chamberlain (eds.) Seaweeds of the British Isles. 1. Rhodophyta, part 2B Corallinales, Hildenbrandiales. pp. 113158. The Natural History Museum, London.

Dawson, E.Y. 1960. Marine red algae of Pacific Mexico. Part 3. Cryptonemiales, Corallinaceae subf. Melobesioideae. Pacific Naturalist 2(1): 3-125.

Desikachary, T.V.\& E.K. GANESAN. 1967. Notes on Indian red algae. IV. Hydrolithon reinboldii (Weber van Bosse et Foslie) Foslie and Hydrolithon iyengarii sp. nov. Phykos 5: 83-90.

Dreckmann, K.M. 1991. Géneros de algas calcificadas de México. I. Nomenclatura y sistemática. Hidrobiológica 1: 29-39.

Foslie, M. 1898. List of species of the Lithothamnia.
Kjelder Norske Videnskabers Selskab skrifter. 1898. (2): 1-7.

Foslie, M. 1901. New Melobesiae. Kjelder Norske Videnskabers Selskab skrifter. 1900 (6): 1-24.

FosLIE, M. 1904. Algologiske notiser. Kjelder Norske Videnskabers Selskab skrifter. 1904 (2): 1-9.

FosLIE, M. 1909. Algologiske notiser. VI. Kjelder Norske Videnskabers Selskab skrifter. 1909 (2): 1-63

Guiry, M. D. \& G. M. Guiry. 2007. AlgaeBase version 4.2. World-wide electronic publication, National University of Ireland, Galway. http://www. algaebase.org

Harvey, A. S., S.T. Broadwater, W. J. Woelkerling \& P. J. Mitrovski. 2003. Choreonema (Corallinales, Rhodophyta): $18 \mathrm{~S}$ rDNA phylogeny and resurrection of the Hapalidaceae for the Subfamilies Choreonematoideae, Austrolithoideae and Melobesioideae. Journal of Phycology 39: 988-998.

HeYdrich, F. 1897. Neve kalkalgen von Deutsch-NeuGuinea (Kaiser Wilhelms-Land). Bibliotheca Botanica 41: 1-11, pl.1.

Heydrich, F. 1901. Die Lithothamnien des Museum d' Histoire Naturelle in Paris. Botanische Jahrbucher 28: 529-545, pl. 11.

Howe, M.A. 1920. Class 2. Algae. In: N.L. Britton \& C.F. Millspaugh (eds.), pp. 553-631. The Bahama Flora.

Huerta, M. L., A.C. Mendoza-GonzÁlez \& L.E. MateoCID. 1987. Avance sobre un estudio de las algas marinas de la Península de Yucatán. Phytologia 62(1): 23-53.

John, D.M., J.H. Price, C. Maggs \& G.W. Lawson. 1979. Seaweeds of the western coast of tropical Africa and adjacent islands: a critical assessment. III. Rhodophyta (Bangiophyceae). Bulletin of the British Museum (Natural History) Botany 7: 69-82.

Keats, D.W. \& Y.M. Chamberlain.1994. Three species of Hydrolithon (Rhodophyta, Corallinaceae): Hydrolithon onkodes (Heydrich) Penrose and Woelkerling, Hydrolithon superficiale sp.nov., and $H$. samoênse (Foslie) comb.nov. from South Africa. South African Journal of Botany 60(1): 8-21, 54 figs.

Lamouroux, J.V.F. 1816. Histoire des Polypiers Corallige 'nes Flexibles, Vulgairement Nomme's Zoophytes. F. Poisson: Caen. 559 pp., 19 pls, 1 chart. Effective publication date: October 1816 (Stafleu \& Cowan 1979, p. 741). An abridged English version was published by an unknown translator in 1824 (see Anonymous 1824).

Lemoine, Mme. P. 1911. Structure anatomique des Melobésiées. Application á la Classification. Annales de l'Institut Oceanographique. Monaco 2(2): $1-213$.

Lemoine, Mme. P. 1917. Corallinaceae. Subfam. I. Melobesieae. In: F. Børgesen (ed.), The marine algae of the Danish West Indies III. Rhodophyceae. Part C. pp. 147-182. Dansk Botanisk Arkiv. 
Gayana Bot. 66(2), 2009

Littler, M.M. 1972. The crustose Corallinaceae. Oceanography and Marine Biology. Annals Review 10: 1-311.

Littler, D. S. \& M.M. Littler. 2000. Caribbean reef plants. Offshore Graphic, Inc. Washington $542 \mathrm{pp}$.

Martoja, R. \& M. Martoja-Pierson. 1970. Técnicas de Histología Animal. Barcelona: Toray-Masson, $370 \mathrm{pp}$.

MASAKI, T. 1968. Studies on the Melobesiodeae of Japan. Memoirs of the Faculty of Fisheries, Hokkaido University 16(1-2): 1-80.

Mateo-Cid, L.E. \& F.F. Pedroche. 2004. The occurrence of Neogoniolithon fosliei (Heydrich) Setchell et Mason in the Mexican Caribbean and the relationship of this species to N. solubile (Foslie et Howe) Setchell et Mason (Corallinales, Rhodophyta). Caribbean Journal of Science. 40(2): 182-191.

Mendoza-González, A.C. \& L.E. Mateo-Cid. 1992. Algas marinas bentónicas de Isla Mujeres, Quintana Roo, México. Acta Botánica Mexicana 19: 37-62

Ortega, M.M., J.L. Godínez \& G. Garduño Solórzano. 2001. Catálogo de algas bénticas de las costas mexicanas del Golfo de México y Mar Caribe. Comisión Nacional para el Estudio de la Biodiversidad y Universidad Nacional Autónoma de México, México, D.F. 594 pp.

Penrose, D.L. 1990. Taxonomic studies on Spongites and Neogoniolithon (Corallinaceae, Rhodophyta) in southern Australia. Unpublished PhD Thesis, La Trobe University, Bundoora, Victoria, Australia.

Penrose, D.L. 1996. Subfamily Mastophoroideae. In: H.B.S Womersley (ed.), The Marine benthic Flora of Southern Australia Part III B. Gracilariales, Rhodymeniales, Corallinales and Bonnemaisoniales, pp. 153-158. Canberra, Australian Biological Resources Study.
Penrose, D.L. \& W.J. Woelkerling. 1988. A taxonomic reassessment of Hydrolithon Foslie, Porolithon Foslie and Pseudolithophyllum Lemoine emend. Adey (Corallinaceae, Rhodophyta) and their relationships to Spongites Kützing. Phycologia 26: 159-176.

Penrose, D.L. \& W.J. Woelkerling. 1992. A reappraisal of Hydrolithon and its relationship to Spongites (Corallinaceae. Rhodophyta). Phycologia 31: 81-88.

Penrose, D.L. \& Y.M. Chamberlain. 1993. Hydrolithon farinosum (J.V. Lamouroux) comb. nov.: implications for generic concepts in the Mastophoroideae (Corallinaceae, Rhodophyta). Phycologia 32: 295-303

Setchell, W.A. 1943. Mastophora and the Mastophorae: Genus and subfamily of Corallinaceae. Proceedings. Natural. Academic Science. 29: 127-135.

TAYLOR, W.R. 1960. Marine algae of the eastern Tropical and Subtropical coasts of the America. University of Michigan Press, Ann Arbor. 870 pp.

Weber-Van Bosse, A. 1904. Corallinaeae verae of the Malay Archipelago. In: A. Weber-van Bosse $\&$ M. Foslie. The Corallinaceae of Siboga Expedition, pp. 78-110. Siboga-Expeditae. Monography (Leiden).

Woelkerling, W.J. 1988. The Coralline Red Algae: An Analysis of the Genera and Subfamilies of Non-geniculate Corallinaceae. Oxford: Oxford University Press and London: British Museum (Natural History), 268 pp.

Woelkerling, W. J. 1993. Type collections of Corallinales (Rhodophyta) in the Foslie Herbarium (TRH). Gunneria 67: 1-289.

Woelkerling, W. J., L.M. Irvine \& A. S. Harvey. 1993. Growth-forms in Non-geniculate Coralline Red Algae (Corallinales, Rhodophyta). Australian Systematic Botany 6: 277-293.

Recibido: 23.02.09

Aceptado: 31.07.09 